\title{
Badanie przyczepności lakierów w układach dwuwarstwowych*
}

W praktyce konserwatorskiej bardzo często spotykamy się z koniecznością nakładania werniksów bądź lakierów w kilku warstwach. Obok braku rozpuszczalności warstwy spodniej przez wierzchnia, istotne znaczenie ma wzajemna ich przyczepność, a także wpływ warstwy wierzchniej na przyczepność spodniej do podłoża. Słaba adhezja spodniej warstwy w zasadzie eliminuje możliwość nanoszenia kolejnych warstw, jednak badania wykazały, że istnieja wyjątki.

W badaniach jako spodnie warstwy obok lakierów, których powłoki wykazują bardzo dobra przyczepność do podłoża, użyto lakiery mające częste zastosowanie w praktyce. Są to:

20\% Paraloid B 44 w 1-metoksy-2-propanolu + barwnik Blau 807 BASF

20\% Regalrez 1094 w white spirit D 40 + farba olejna Indian Yellow 244 Van Gogh Talens

11\% Paraloid B-48N w [acetonie + DPM ${ }^{1}$ (1:1)] + Savinyl Rot RLSN Clariant

14\% Paraloid B-72 w [toluenie + DPM (2:1)] + barwnik Blue 807 BASF

* Niniejszy artykuł to prezentacja wyników badań dotyczących przyczepności lakierów, będący fragmentem rozprawy habilitacyjnej J. Stachery, Historyczne i wspótczesne lakiery w sžtuce. Wtaściwości. Zagadnienia rekonstrukecii w praktyce konserwatorskiej, Toruń 2012.

1 DPM - synonim eter metylowy glikolu dipropylenowego 
14\% Laropal A $81 \mathrm{w}$ [alkoholu etylowym + DPM (2:1)]

$15 \%$ Szelak bielony w alkoholu butylowym

20\% Szelak bielony w metoksy-2-propanolu + barwnik Blau 807 BASF

15\% Sandarak w alkoholu butylowym + barwnik Savinyl Gelb RLSN Clariant

$15 \%$ Sandarak w [alkoholu etylowym + DPM (2:1)] + barwnik Savinyl Gelb RLSN Clariant

Olej lniany, mastyks, olejek terpentynowy $(1: 1: 1)$ + sykatywa kobaltowa

Lakier kopalowo-olejny w olejku terpentynowym + farba olejna Indian Yellow 244 Van Gogh Talens

Acrylic Varnish Glossy 114 Talens + farba olejna Indian Yellow 244 Van Gogh Talens

Bernsteinlack echt Kremer + farba olejna Indian Yellow 244 Van Gogh Talens

Decorfin Glass Yellow 200 Talens

Zaponlack Kremer + barwnik Savinyl Gelb RLSN Clariant

Incral 44 CTS + barwnik Savinyl Gelb RLSN Clariant

Lakier szelakowy citron + DPM (2:1)

Lustrina Restaurarte + DPM (2:1) + barwnik Savinyl Gelb RLSN Clariant

Idea Vetro 070 Yellow Maimeri + DPM (2:1)

Jako wierzchnie warstwy zastosowano szeroką gamę lakierów, które nie powoduja rozpuszczenia spodniej warstwy.

Badania wykonano według opisu zawartego w normie PN-EN ISO 2409. Metoda polega na określeniu stopnia przyczepności lakieru poprzez wykonanie siatki nacięć przy użyciu noża krążkowego, mającego 6 równolegle umieszczonych ostrzy, w odstępach $1 \mathrm{~mm}$.

Przygotowanie próbek. Na płytki mosiężne o wymiarach $0,3 \times 100 \times 50 \mathrm{~mm}$, po oczyszczeniu acetonem i wysuszeniu, naniesiono przy użycia pędzla nylonowego lakiery. Drugą warstwę naniesiono po upływie 48 godzin od nałożenia pierwszej. Zabieg przeprowadzono w temperaturze $20^{\circ} \mathrm{C}$ i wilgotności względnej powietrza $50 \pm 5 \%$. Płytki z naniesionymi lakierami poddano procesowi suszenia przez okres 4 miesięcy.

Przebieg badania. Na płytkach pokrytych lakierami wykonywano nacięcia równoległe nożem krążkowym, a następnie pod kątem prostym 
kolejne nacięcia przecinające poprzednie. Powstawała siatka nacięć składająca się z 25 kwadratów, wykonano po 6 siatek nacięć. Płytki oczyszczono szczoteczką, a następnie naklejono taśmę samoprzylepna, którą dociśnięto palcem. Po upływie 5 minut taśmę oderwano. Oceny powstałych uszkodzeń dokonywano przy użyciu szkła o trzykrotnym powiększeniu oraz pod mikroskopem. Ilość i procent powstałych ubytków i stopień uszkodzenia ubytku określano w sześciostopniowej skali od 0 do 5 podanej w normie (im mniejsza wartość, tym lepsza przyczepność).

W przeprowadzonych badaniach obok oceny przyczepności warstwy spodniej do podłoża, wierzchniej do spodniej, próbowano ustalić, czy istnieje zauważalna granica między obiema warstwami, brak jej może świadczyć o naruszeniu spodniej warstwy przez wierzchnia. W celu łatwiejszej analizy przyczepności między warstwami lakiery podbarwiono barwnikami i farbami olejnymi.

Uzyskane wyniki przedstawione zostały w formie tabel z opisem i krótkim komentarzem zamieszczonym pod tabela. 
Tabela I. Lakiery dwuwarstwowe - badanie przyczepności (po 4 miesiącach od nałożenia), temp $20^{\circ} \mathrm{C}$, wilg. $30 \%$

\begin{tabular}{|c|c|c|c|}
\hline $\begin{array}{l}\text { Lakier - war- } \\
\text { stwa spodnia }\end{array}$ & Lakier - warstwa wierzchnia & Wynik & Opis \\
\hline \multirow{18}{*}{$\begin{array}{l}20 \% \text { Paraloid B } \\
44 \text { w 1-metoksy- } \\
2 \text {-propanolu }+ \\
\text { barwnik Blau } 807 \\
\text { BASF } \\
\text { Warunki nakłada- } \\
\text { nia - Temp 20C, } \\
\text { wilg. } 50 \% \text {. Oce- } \\
\text { na przyczepności } \\
\text { pojedynczej war- } \\
\text { stwy: } 2,3\end{array}$} & $\begin{array}{l}\text { 20\% Regalrez } 1094 \text { w white spirit D40 + far- } \\
\text { ba olejna Indian Yellow } 244 \text { Van Gogh Ta- } \\
\text { lens }\end{array}$ & 2,3 & $\begin{array}{l}\text { Powierzchnia półmatowa, po oderwaniu taśmy ma- } \\
\text { towa. Drobiny wierzchniej warstwy odeszły z taśmą. } \\
\text { U góry stopień ubytku wierzchniej warstwy, u do- } \\
\text { łu spodniej }\end{array}$ \\
\hline & $\begin{array}{l}\text { 11\% Paraloid B-72 w [alkoholu etylowym } \\
+ \text { DPM (1:1)] + barwnik Savinyl Rot RLSN } \\
\text { Clariant }\end{array}$ & 1,9 & $\begin{array}{l}\text { Powierzchnia błyszcząca. Dobra adhezja między } \\
\text { warstwami (brak wyraźnej granicy). Ocena stopnia } \\
\text { ubytku dotyczy obu warstw }\end{array}$ \\
\hline & $\begin{array}{l}\text { 20\% Szelak bielony w alkoholu etylowym + } \\
\text { barwnik Savinyl Rot RLSN Clariant }\end{array}$ & 2,6 & $\begin{array}{l}\text { Wierzchnia warstwa dobrze się nanosi. Powierzch- } \\
\text { nia błyszcząca. Dobra adhezja między warstwami } \\
\text { (widoczna granica). Ocena stopnia ubytku doty- } \\
\text { czy obu warstw }\end{array}$ \\
\hline & $\begin{array}{l}\text { 20\% Sandarak w alkoholu butylowym + } \\
\text { barwnik Savinyl Gelb RLSN Clariant + barw- } \\
\text { nik Blau } 807 \text { BASF }\end{array}$ & 2,4 & $\begin{array}{l}\text { Powierzchnia błyszcząca. Po oderwaniu taśmy bar- } \\
\text { dzo delikatne zmatowienie wierzchniej warstwy. } \\
\text { Dobra adhezja między warstwami (brak wyraźnej } \\
\text { granicy). Ocena stopnia ubytku dotyczy obu warstw }\end{array}$ \\
\hline & $\begin{array}{l}\text { 14\% Szelak bielony w [alkoholu etylowym } \\
+ \text { DPM (2:1)] + barwnik Savinyl Rot RLSN } \\
\text { Clariant }\end{array}$ & 1,6 & $\begin{array}{l}\text { Powierzchnia błyszcząca. Dobra adhezja między } \\
\text { warstwami (brak wyraźnej granicy). Ocena stopnia } \\
\text { ubytku dotyczy obu warstw }\end{array}$ \\
\hline & $\begin{array}{l}\text { 14\% Szelak złocisty (nieodwosk.) w [alkoho- } \\
\text { lu etylowym + DPM (2:1)] + barwnik Blau } \\
807 \text { BASF }\end{array}$ & 2,7 & $\begin{array}{l}\text { Powierzchnia błyszcząca. Dobra adhezja między } \\
\text { warstwami (brak wyraźnej granicy). Ocena stopnia } \\
\text { ubytku dotyczy obu warstw }\end{array}$ \\
\hline & \multirow{2}{*}{$\begin{array}{l}\text { Olej Iniany, mastyks, olejek terpentyno- } \\
\text { wy }(1: 1: 1) \text { + farba olejna Rose Madder } 329 \\
\text { Rembrandt Talens }\end{array}$} & 2,3 & \multirow{2}{*}{$\begin{array}{l}\text { Powierzchnia błyszcząca. U góry ocena stopnia } \\
\text { ubytku wierzchniej warstwy, u dołu ubytku spodniej }\end{array}$} \\
\hline & & 1,6 & \\
\hline & $\begin{array}{l}\text { Kopal z Madagaskaru, olej Iniany, olejek ter- } \\
\text { pentynowy (2:1:2) + farba olejna Indian Yel- } \\
\text { low } 244 \text { Van Gogh Talens }\end{array}$ & 2,3 & $\begin{array}{l}\text { Niewielkie zabielenie warstwy, po wyschnięciu ustą- } \\
\text { piło. Powierzchnia błyszcząca. Dobra adhezja mię- } \\
\text { dzy warstwami (widoczna granica). Ocena stopnia } \\
\text { ubytku dotyczy obu warstw }\end{array}$ \\
\hline & $\begin{array}{l}\text { Acrylic Varnish Glossy } 114 \text { Talens + farba } \\
\text { olejna Indian Yellow } 244 \text { Van Gogh Talens }\end{array}$ & 2,6 & $\begin{array}{l}\text { Powierzchnia błyszcząca. Dobra adhezja między } \\
\text { warstwami (widoczna granica). Ocena stopnia ubyt- } \\
\text { ku dotyczy obu warstw }\end{array}$ \\
\hline & \multirow[t]{2}{*}{$\begin{array}{l}\text { Damara Varnish Glossy } 081 \text { Talens + farba } \\
\text { olejna Phthalo Blue } 570 \text { Rembrandt }\end{array}$} & 2,3 & \multirow{2}{*}{$\begin{array}{l}\text { Powierzchnia błyszcząca. Po oderwaniu taśmy bar- } \\
\text { dzo delikatne zmatowienie warstwy wierzchniej. } \\
\text { U góry ocena stopnia ubytku wierzchniej warstwy, } \\
\text { u dołu spodniej }\end{array}$} \\
\hline & & 1,3 & \\
\hline & $\begin{array}{l}\text { Decorfin Glass Yellow } 200 \text { Talens + whi- } \\
\text { te spirit D } 40\end{array}$ & 3,2 & $\begin{array}{l}\text { Powierzchnia błyszcząca. Dobra adhezja między } \\
\text { warstwami (widoczna granica). Ocena stopnia ubyt- } \\
\text { ku dotyczy obu warstw }\end{array}$ \\
\hline & $\begin{array}{l}\text { Zaponlack Kremer + barwnik Savinyl Rot } \\
\text { RLSN Clariant }\end{array}$ & 1,4 & $\begin{array}{l}\text { Powierzchnia błyszcząca, po oderwaniu taśmy bez } \\
\text { zmian. Dobra adhezja między warstwami (brak wy- } \\
\text { raźnej granicy). Ocena stopnia uszkodzenia doty- } \\
\text { czy obu warstw }\end{array}$ \\
\hline & $\begin{array}{l}\text { Lustrina Restaurarte + DPM (2:1) + barwnik } \\
\text { Savinyl Gelb RLSN Clariant }\end{array}$ & 3,0 & $\begin{array}{l}\text { Powierzchnia błyszcząca. Dobra adhezja między } \\
\text { warstwami (widoczna granica). Ocena stopnia ubyt- } \\
\text { ku dotyczy obu warstw }\end{array}$ \\
\hline & $\begin{array}{l}\text { Idea Vetro } 070 \text { Yellow Maimeri + DPM (2:1) } \\
\text { + barwnik Savinyl Rot RLSN Clariant }\end{array}$ & 3,7 & $\begin{array}{l}\text { Powierzchnia błyszcząca. Dobra adhezja mię- } \\
\text { dzy warstwami (widoczna granica). Ocena stopnia } \\
\text { uszkodzenia dotyczy obu warstw }\end{array}$ \\
\hline & \multirow{2}{*}{$\begin{array}{l}\text { Damara, olej Iniany, olejek terpentynowy } \\
\text { (2:3:3) + farba olejna Indian Yellow } 244 \text { Van } \\
\text { Gogh Talens }\end{array}$} & 1,3 & \multirow{2}{*}{$\begin{array}{l}\text { Powierzchnia błyszcząca. Dobra adhezja między } \\
\text { warstwami (widoczna granica). U góry ocena stop- } \\
\text { nia ubytku wierzchniej warstwy, u dołu spodniej }\end{array}$} \\
\hline & & 1,0 & \\
\hline
\end{tabular}


Powłoka Paraloidu B-44 w 1-metoksy-2-propanolu, której ocena przy badaniu przyczepności wynosiła około 2,3, po naniesieniu warstwy innego lakieru nie utraciła w znaczący sposób adhezji do podłoża, a w kilku konfiguracjach odnotowano jej poprawę. Zauważalna poprawa przyczepności wystapiła po naniesieniu jako drugiej warstwy 14\% szelaku bielonego w alkoholu etylowym z dodatkiem DPM i Zaponlacku Kremer. Również bardzo dobry rezultat uzyskano po naniesieniu lakieru olejnego-żywicznego o składzie: damara, olej lniany, olejek terpentynowy. Po nałożeniu jako wierzchnie warstwy lakierów z żywic sztucznych i naturalnych rozpuszczonych w alkoholu etylowym bądź butylowym nie zaobserwowano wyraźnej granicy miedzy warstwami. 


\begin{tabular}{|c|c|c|c|}
\hline \multicolumn{4}{|c|}{$\begin{array}{l}\text { Tabela II. Lakiery dwuwarstwowe - badanie przyczepności (po } 4 \text { miesiącach od nałożenia), } \\
\text { temp } 20^{\circ} \mathrm{C} \text {, wilg. } 30 \%\end{array}$} \\
\hline Lakier - warstwa spodnia & Lakier - warstwa wierzchnia & Wynik & Opis \\
\hline \multirow{4}{*}{$\begin{array}{l}20 \% \quad \text { Regalrez } 1094 \\
\text { w white spirit D40 + farba } \\
\text { olejna Indian Yellow } 244 \\
\text { Van Gogh Talens }\end{array}$} & \multirow{2}{*}{$\begin{array}{l}\text { 15\% Paraloid B-72 w 1-metoksy- } \\
\text {-2-propanolu + barwnik Blau } 807 \\
\text { BASF }\end{array}$} & 5,0 & \multirow{2}{*}{$\begin{array}{l}\text { Dobrze, równomiernie się nanosi. Wierzchnia war- } \\
\text { stwa odeszła z taśmą. U góry ocena stopnia ubytku } \\
\text { wierzchniej warstwy, u dołu spodniej (w miejscach } \\
\text { ubytku wierzchniej warstwy powierzchnia spodniej } \\
\text { silnie uszkodzona) }\end{array}$} \\
\hline & & 2,8 & \\
\hline & \multirow{2}{*}{$\begin{array}{l}11 \% \text { Paraloid B-48N w [acetonie + } \\
\text { DPM (1:1)] + barwnik Savinyl Rot } \\
\text { RLSN Clariant }\end{array}$} & 5,0 & \multirow{2}{*}{$\begin{array}{l}\text { Warstwy odeszły razem z taśmą. U góry ocena } \\
\text { stopnia ubytku wierzchniej warstwy, u dołu uszko- } \\
\text { dzenia spodniej }\end{array}$} \\
\hline & & 2,8 & \\
\hline \multirow{16}{*}{$\begin{array}{l}\text { Ocena przyczepności poje- } \\
\text { dynczej warstwy: } 2,8\end{array}$} & \multirow{2}{*}{$\begin{array}{l}15 \% \text { Sandarak w alkoholu butylo- } \\
\text { wym + barwnik Savinyl Rot RLSN } \\
\text { Clariant }\end{array}$} & 2,0 & \multirow{2}{*}{$\begin{array}{l}\text { Zmatowienie i zabielenie warstwy! Warstwa bar- } \\
\text { dzo krucha. Brzydki efekt! Po oderwaniu taśmy po- } \\
\text { wierzchnia bardziej matowa. U góry ocena stopnia } \\
\text { ubytku wierzchniej warstwy, u dołu uszkodzenia } \\
\text { spodniej (mikrospękania) }\end{array}$} \\
\hline & & 2,0 & \\
\hline & \multirow{2}{*}{$\begin{array}{l}\text { 14\% Szelak bielony w [alkoholu } \\
\text { etylowym + DPM (2:1)] + barwnik } \\
\text { Blau } 807 \text { BASF }\end{array}$} & 5,0 & \multirow{2}{*}{$\begin{array}{l}\text { Powierzchnia lekko błyszcząca, po oderwaniu taśmy } \\
\text { wierzchnia warstwa odeszła razem z nią. U góry } \\
\text { ocena stopnia ubytku wierzchniej warstwy, u dołu } \\
\text { ubytku spodniej }\end{array}$} \\
\hline & & 2,2 & \\
\hline & \multirow{2}{*}{$\begin{array}{l}\text { 14\% Szelak złocisty (nieodwosk.) } \\
\text { W [alkoholu etylowym + DPM } \\
(2: 1)] \text { + barwnik Blau } 807 \text { BASF }\end{array}$} & 5,0 & \multirow{2}{*}{$\begin{array}{l}\text { Powierzchnia lekko błyszcząca, po oderwaniu taśmy } \\
\text { wierzchnia warstwa odeszła razem z nią. U góry } \\
\text { ocena stopnia ubytku wierzchniej warstwy, u do- } \\
\text { łu spodniej }\end{array}$} \\
\hline & & 1,8 & \\
\hline & \multirow[t]{2}{*}{ Lakier szelakowy blue + DPM (2:1) } & 4,4 & \multirow{2}{*}{$\begin{array}{l}\text { Powierzchnia lekko błyszcząca, po oderwaniu taśmy } \\
\text { wierzchnia warstwa odeszła razem z nią. U góry } \\
\text { ocena stopnia ubytku wierzchniej warstwy, u do- } \\
\text { łu spodniej }\end{array}$} \\
\hline & & 2,0 & \\
\hline & $\begin{array}{l}\text { Lustrina Restaurarte + DPM (2:1) } \\
+ \text { barwnik Savinyl Gelb RLSN Cla- } \\
\text { riant }\end{array}$ & 2,8 & $\begin{array}{l}\text { Powierzchnia błyszcząca. Dobra adhezja między } \\
\text { warstw (widoczna granica między warstwami). Oce- } \\
\text { na stopnia ubytku dotyczy obu warstw }\end{array}$ \\
\hline & \multirow{2}{*}{$\begin{array}{l}\text { Zaponlack Kremer + DPM (1:1)] + } \\
\text { barwnik Savinyl Rot RLSN Clariant }\end{array}$} & 4,8 & \multirow{2}{*}{$\begin{array}{l}\text { Powierzchnia błyszcząca, po oderwaniu taśmy } \\
\text { wierzchnia warstwa odeszła razem z nią. U góry } \\
\text { ocena stopnia ubytku wierzchniej warstwy, u do- } \\
\text { łu spodniej }\end{array}$} \\
\hline & & 2,0 & \\
\hline & \multirow{2}{*}{$\begin{array}{l}\text { Idea Vetro Rose } 202 \text { Maimeri + } \\
\text { DPM (2:1) }\end{array}$} & 3,3 & \multirow{2}{*}{$\begin{array}{l}\text { Powierzchnia błyszcząca. Warstwa wierzchnia na } \\
\text { jednej płytce częściowo odeszły razem z taśmą. } \\
\text { U góry ocena stopnia ubytku wierzchniej warstwy, } \\
\text { u dołu uszkodzenia spodniej }\end{array}$} \\
\hline & & 3,3 & \\
\hline & $\begin{array}{l}\text { Damara, olej Iniany, olejek terpen- } \\
\text { tynowy (2:3:3) + farba olejna In- } \\
\text { dian Yellow } 244 \text { Van Gogh Talens }\end{array}$ & 0,9 & $\begin{array}{l}\text { Dodatek olejku terpentynowego powoduje rozpusz- } \\
\text { czanie spodniej warstwy, co uwidacznia się w po- } \\
\text { marszczeniu powierzchni. Brzydki efekt! Ocena } \\
\text { stopnia ubytku dotyczy obu warstw }\end{array}$ \\
\hline & \multirow{2}{*}{$\begin{array}{l}\text { 20\% Szelak bielony w 1-metoksy- } \\
\text {-2-propanolu + barwnik Blau } 807 \\
\text { BASF }\end{array}$} & 4,8 & \multirow{2}{*}{$\begin{array}{l}\text { Powierzchnia błyszcząca, po oderwaniu taśmy } \\
\text { wierzchnia warstwa odeszła razem z nią. U góry } \\
\text { ocena stopnia ubytku wierzchniej warstwy, u do- } \\
\text { łu spodniej }\end{array}$} \\
\hline & & 2,2 & \\
\hline
\end{tabular}


Powłoka Regalrezu 1094 również nie wykazywała dobrej przyczepności do podłoża, w badaniu pojedynczej warstwy oceniano ją na 2,8. Po naniesieniu na powierzchnię Regalrezu 1094 warstw lakieru z żywic sztucznych rozpuszczonych w 1-metoksy-2-propanolu i acetonie z dodatkiem DPM stwierdzono brak ich przyczepności do spodniej warstwy. Podczas badania odchodziły one wraz z taśma. Analogicznie zachowywały się warstwy lakierów szelakowych w alkoholu etylowym i 1-metoksy-2-propanolu, a także Zaponlacku Kremer. Jedynie przyczepność powłoki lakieru sandarakowego w alkoholu butylowym do spodniej warstwy była stosunkowo dobra. Lakier olejno-żywiczny (damara, olej lniany, olejek terpentynowy) ze względu na zawartość olejku terpentynowego powodował rozpuszczanie się spodniej warstwy, ale przyczepność obu warstw do podłoża była bardzo dobra. 


\begin{tabular}{|c|c|c|c|}
\hline \multicolumn{4}{|c|}{$\begin{array}{c}\text { Tabela III. Lakiery dwuwarstwowe - badanie przyczepności (po } 4 \text { miesiącach od nałożenia), } \\
\text { temp } 20^{\circ} \mathrm{C} \text {, wilg. } 30 \%\end{array}$} \\
\hline Lakier - warstwa spodnia & Lakier - warstwa wierzchnia & Wynik & Opis \\
\hline \multirow{19}{*}{$\begin{array}{l}\text { 11\% Paraloid B-48N } \\
\text { w [acetonie + DPM (1:1)] + } \\
\text { Savinyl Rot RLSN Clariant } \\
\text { Warunki nakładania } \\
\text { Temp 20C, wilg. 50\% } \\
\text { Ocena przyczepności poje- } \\
\text { dynczej warstwy: 0,0 }\end{array}$} & \multirow{2}{*}{$\begin{array}{l}\text { 20\% Regalrez } 1094 \text { w white spirit } \\
\text { D40 + farba olejna Indian Yellow } \\
\text { Van Gogh Talens }\end{array}$} & 1,3 & \multirow{2}{*}{$\begin{array}{l}\text { Powierzchnia półmatowa. Brzydki efekt! Po ode } \\
\text { rwaniu taśmy matowa. Drobiny wierzchniej war } \\
\text { stwy odeszła z taśmą. U góry ocena stopnia ubytk } \\
\text { wierzchniej warstwy, u dołu uszkodzenia spodniej }\end{array}$} \\
\hline & & 0,2 & \\
\hline & $\begin{array}{l}11 \% \text { Paraloid B-72 w [alkoholu } \\
\text { etylowym + DPM (1:1)] + barwnik } \\
\text { Blau } 807 \text { BASF }\end{array}$ & 0,0 & $\begin{array}{l}\text { Powierzchnia błyszcząca. Dobra adhezja między } \\
\text { warstwami (brak wyraźnej granicy). Ocena stopnia } \\
\text { uszkodzenia dotyczy obu warstw }\end{array}$ \\
\hline & \multirow{2}{*}{$\begin{array}{l}15 \% \text { Szelak bielony w alkoholu } \\
\text { etylowym + barwnik Savinyl Rot } \\
\text { RLSN Clariant }\end{array}$} & 4,1 & \multirow{2}{*}{$\begin{array}{l}\text { Powierzchnia błyszcząca, po oderwaniu taśmy } \\
\text { wierzchnia warstwa odeszła razem z nią. U góry } \\
\text { ocena stopnia ubytku wierzchniej warstw, spodnia } \\
\text { zachowała bardzo dobrą przyczepność }\end{array}$} \\
\hline & & 0,0 & \\
\hline & $\begin{array}{l}15 \% \text { Sandarak w alkoholu butylo- } \\
\text { wym + barwnik Savinyl Rot RLSN } \\
\text { Clariant }\end{array}$ & 0,0 & $\begin{array}{l}\text { Powierzchnia błyszcząca. Dobra adhezja między } \\
\text { warstwami (brak wyraźnej granic). Ocena stopnia } \\
\text { uszkodzenia dotyczy obu warstw }\end{array}$ \\
\hline & \multirow{2}{*}{\begin{tabular}{|l|} 
Olej Iniany, mastyks, olejek terpen- \\
tynowy $(1: 1: 1)+$ farba olejna Ro- \\
se Madder 329 Rembrandt Talens \\
\end{tabular}} & 2,7 & \multirow{2}{*}{$\begin{array}{l}\text { Powierzchnia błyszcząca. U góry ocena stopnia } \\
\text { ubytku wierzchniej warstwy, spodnia zachowała } \\
\text { bardzo dobrą przyczepność }\end{array}$} \\
\hline & & 0,0 & \\
\hline & \multirow{2}{*}{\begin{tabular}{|l|} 
Kopal z Madagaskaru, olej Iniany, \\
olejek terpentynowy (2:1:2) + farba \\
olejna Indian Yellow 244
\end{tabular}} & 2,5 & \multirow{2}{*}{$\begin{array}{l}\text { Powierzchnia błyszcząca. U góry ocena stop- } \\
\text { nia ubytku wierzchniej warstwy, u dołu spodniej. } \\
\text { Spodnia zachowała bardzo dobrą przyczepność }\end{array}$} \\
\hline & & 0,0 & \\
\hline & \begin{tabular}{|l|} 
Acrylic Varnish Picture Glossy 114 \\
Talens + farba olejna Indian Yellow \\
244 Van Gogh Talens \\
\end{tabular} & 0,0 & $\begin{array}{l}\text { Warstwa pótmatowa. Pod mikroskopem widoczne } \\
\text { drobimy farby olejnej. Dobra adhezja między war- } \\
\text { stwami }\end{array}$ \\
\hline & \multirow{2}{*}{$\begin{array}{l}\text { Damara Varnish Glossy } 081 \text { Ta- } \\
\text { lens + farba olejna Phthalo Blue } \\
570 \text { Rembrandt Talens }\end{array}$} & 2,0 & \multirow{2}{*}{$\begin{array}{l}\text { Powierzchnia lekko błyszcząca, po oderwaniu taśmy } \\
\text { matowa. U góry ocena stopnia ubytku wierzchnie } \\
\text { warstwy, spodnia zachowała bardzo dobrą przy- } \\
\text { czepność }\end{array}$} \\
\hline & & 0,0 & \\
\hline & \multirow{2}{*}{\begin{tabular}{|l|} 
Decorfin Glass blue $500+501$ Ta- \\
lens + white spirit D40 (2:1)
\end{tabular}} & 3,6 & \multirow{2}{*}{$\begin{array}{l}\text { Powierzchnia błyszcząca. Część wierzchniej warstwy } \\
\text { odeszła razem z taśmą. Ocena stopnia uszkodzenia } \\
\text { dotyczy wierzchniej warstw, spodnia zachowała bar- } \\
\text { dzo dobrą przyczepność }\end{array}$} \\
\hline & & 0,0 & \\
\hline & $\begin{array}{l}\text { Zaponlack Kremer + barwnik Savi- } \\
\text { nyl Rot RLSN Clariant }\end{array}$ & 0,0 & $\begin{array}{l}\text { Powierzchnia błyszcząca. Bardzo dobra adhezja } \\
\text { warstw. Ocena stopnia uszkodzenia dotyczy obu } \\
\text { warstw }\end{array}$ \\
\hline & $\begin{array}{l}\text { Idea Vetro } 202 \text { Rose Maimeri + } \\
\text { DPM (2:1) }\end{array}$ & 0,2 & $\begin{array}{l}\text { Powierzchnia błyszcząca. Bardzo dobra adhezja } \\
\text { warstw. Ocena stopnia uszkodzenia dotyczy obu } \\
\text { warstw }\end{array}$ \\
\hline & \multirow{2}{*}{\begin{tabular}{|l} 
Damara, olej Iniany, olejek terpen- \\
tynowy (2:3:3) + farba olejna In- \\
dian Yellow 244 Van Gogh Talens
\end{tabular}} & 0,8 & \multirow{2}{*}{$\begin{array}{l}\text { Powierzchnia błyszcząca. Dobra adhezja między } \\
\text { warstwami (widoczna granica). U góry ocena stop- } \\
\text { nia ubytku wierzchniej warstwy, spodnia zachowała } \\
\text { bardzo dobrą przyczepność }\end{array}$} \\
\hline & & 0,0 & \\
\hline
\end{tabular}


Doskonała przyczepność powłoki lakieru Paraloidu B-48N w acetonie $z$ dodatkiem DPM do powierzchni metalu nie uległa zmianie również w opracowaniach dwuwarstwowych. Bardzo dobra przyczepność do powłoki Paraloidu B-44N bez utraty jej przyczepności do podłoża wykazują warstwy lakierów: Paraloidu B-72 w alkoholu etylowym z dodatkiem DPM, sandaraku w alkoholu butylowym, z gotowych produktów werniksu Acrylic Varnish Picture Glossy 114 Talens, lakieru Zaponlack Kremer i farby do szkła Idea Vetro Maimeri. Stosunkowo słabą przyczepność do powłoki Paraloidu B-48N wykazały farby do szkła Decorfin Glass Talens, natomiast bardzo słabą warstwa szelaku bielonego w alkoholu etylowym. 


\begin{tabular}{|c|c|c|c|}
\hline \multicolumn{4}{|c|}{$\begin{array}{c}\text { Tabela IV. Lakiery dwuwarstwowe - badanie przyczepności (po } 4 \text { miesiącach od nałożenia), } \\
\text { temp } 20^{\circ} \mathrm{C} \text {, wilg. } 30 \%\end{array}$} \\
\hline Lakier - warstwa spodnia & Lakier - warstwa wierzchnia & Wynik & Opis \\
\hline \multirow{20}{*}{$\begin{array}{l}\text { 14\% Paraloid B-72 w [to- } \\
\text { luenie + DPM (2:1)] + } \\
\text { barwnik Blue } 807 \text { BASF } \\
\text { Warunki nakładania } \\
\text { Temp 20C, wilg. } 50 \% \\
\text { Ocena przyczepności poje- } \\
\text { dynczej warstwy: 0,4 }\end{array}$} & \multirow{2}{*}{$\begin{array}{l}\text { 20\% Regalrez } 1094 \text { w white spirit } \\
\text { D40 + farba olejna Indian Yellow } \\
\text { Van Gogh Talens }\end{array}$} & 1,0 & \multirow{2}{*}{$\begin{array}{l}\text { Warstwa półmatowa. Po oderwaniu taśmy matowa. } \\
\text { Drobiny wierzchniego lakieru odeszły razem z ta- } \\
\text { śmą. Dobra adhezja miedzy warstwami (widoczna } \\
\text { granica). U góry ocena stopnia ubytku wierzchniej } \\
\text { warstwy, u dołu spodniej }\end{array}$} \\
\hline & & 0,5 & \\
\hline & \multirow{2}{*}{$\begin{array}{l}\text { 15\% Szelak złocisty w alkoholu } \\
\text { butylowym] + barwnik Blau } 807 \\
\text { BASF }\end{array}$} & 5,0 & \multirow{2}{*}{$\begin{array}{l}\text { Powierzchnia błyszcząca, po oderwaniu taśmy } \\
\text { wierzchnia warstwa odeszła razem z nią. Bardzo sła- } \\
\text { ba adhezja między warstwami. U góry ocena stop- } \\
\text { nia ubytku wierzchniej warstwy, u dołu spodniej }\end{array}$} \\
\hline & & 0,7 & \\
\hline & \multirow{2}{*}{$\begin{array}{l}\text { Olej Iniany, mastyks, olejek terpen- } \\
\text { tynowy (1:1:1) } \\
+ \text { farba olejna Rose Madder } 329 \\
\text { Rembrandt Talens }\end{array}$} & 2,8 & \multirow{2}{*}{$\begin{array}{l}\text { Powierzchnia błyszcząca. U góry ocena stopnia } \\
\text { ubytku wierzchniej warstwy, u dołu spodniej }\end{array}$} \\
\hline & & 0,6 & \\
\hline & \multirow{2}{*}{$\begin{array}{l}\text { Kopal z Madagaskaru, olej Iniany, } \\
\text { olejek terpentynowy (2:1:2) } \\
\text { + farba olej. Indian Yellow } 244\end{array}$} & 2,8 & \multirow[t]{2}{*}{$\begin{array}{l}\text { Powierzchnia błyszcząca. U góry ocena stopnia } \\
\text { ubytku wierzchniej warstwy, u dołu spodniej }\end{array}$} \\
\hline & & 0,7 & \\
\hline & \multirow{2}{*}{$\begin{array}{l}\text { Acrylic Varnish Picture Glossy } 114 \\
\text { Talens + farba olejna Indian Yellow } \\
244 \text { Van Gogh Talens }\end{array}$} & 2,7 & \multirow{2}{*}{$\begin{array}{l}\text { Powierzchnia lekko błyszcząca. Podczas oderwania } \\
\text { taśmy nastąpiło częściowe oderwanie wierzchniej } \\
\text { warstwy od spodniej. U góry ocena stopnia ubytku } \\
\text { dotyczy wierzchniej warstwy, u dołu spodniej }\end{array}$} \\
\hline & & 0,3 & \\
\hline & \multirow{2}{*}{$\begin{array}{l}\text { Damara Varnish Glossy } 081 \text { Ta- } \\
\text { lens + farba olejna Phthalo Blue } \\
570 \text { Rembrandt Talens }\end{array}$} & 1,5 & \multirow{2}{*}{$\begin{array}{l}\text { Powierzchnia błyszcząca, po oderwaniu taśmy } \\
\text { matowa. U góry ocena stopnia ubytku dotyczy } \\
\text { wierzchniej warstwy, u dołu spodniej }\end{array}$} \\
\hline & & 0,3 & \\
\hline & \multirow{2}{*}{$\begin{array}{l}\text { Picture Varnish Glossy } 002 \text { Talens } \\
\text { + farba olejna Phthalo Blue Green } \\
576 \text { Rembrandt Talens }\end{array}$} & 1,8 & \multirow{2}{*}{$\begin{array}{l}\text { Powierzchnia błyszcząca, po oderwaniu taśmy lek- } \\
\text { ko matowa. U góry ocena stopnia ubytku dotyczy } \\
\text { wierzchniej warstwy, u dołu spodniej }\end{array}$} \\
\hline & & 0,3 & \\
\hline & $\begin{array}{l}\text { Bernsteinlack echt Kremer + farba } \\
\text { olejna Indian Yellow } 244 \text { Van } \\
\text { Gogh Talens }\end{array}$ & 1,4 & $\begin{array}{l}\text { Powierzchnia błyszcząca. Dobra adhezja obu warstw } \\
\text { (widoczna granica). Ocena stopnia ubytku dotyczy } \\
\text { obu warstw }\end{array}$ \\
\hline & \multirow{2}{*}{$\begin{array}{l}\text { Decorfin Glass Yellow } 200 \text { Talens } \\
+ \text { + white spirit D } 40 \text { (2:1) }\end{array}$} & 3,0 & \multirow{2}{*}{$\begin{array}{l}\text { Powierzchnia błyszcząca. Podczas odrywania taśmy } \\
\text { nastąpiło częściowe oderwanie wierzchniej war- } \\
\text { stwy lakieru. U góry ocena stopnia ubytku dotyczy } \\
\text { wierzchniej warstwy, u dołu spodniej }\end{array}$} \\
\hline & & 1,5 & \\
\hline & $\begin{array}{l}\text { Idea Vetro Rose } 202 \text { Maimeri DPM } \\
(3: 1)\end{array}$ & 2,7 & $\begin{array}{l}\text { Powierzchnia błyszcząca. Bardzo dobra adhezja obu } \\
\text { warstw (widoczna granica). Ocena stopnia uszko- } \\
\text { dzenia dotyczy obu warstw }\end{array}$ \\
\hline & \multirow{2}{*}{$\begin{array}{l}\text { Damara, olej Iniany, olejek terpen- } \\
\text { tynowy (2:3:3) + farba olejna In- } \\
\text { dian Yellow } 244 \text { Van Gogh Talens }\end{array}$} & 2,4 & \multirow{2}{*}{$\begin{array}{l}\text { Powierzchnia błyszcząca. Podczas odrywania taśmy } \\
\text { nastąpiło częściowe oderwanie wierzchniej war- } \\
\text { stwy lakieru. U góry ocena stopnia ubytku dotyczy } \\
\text { wierzchniej warstwy, u dołu spodniej }\end{array}$} \\
\hline & & 0,3 & \\
\hline
\end{tabular}


Naniesienie drugiej warstwy innego lakieru na powierzchnię powłoki z Paraloidu B-72 w większości przypadków nie wpłynęło negatywnie na jej przyczepność do podłoża. Jedynie farby do szkła Decorfin Gass Talens i Idea Vetro Maimeri oraz lakieru Bernsteinlack echt Kremer spowodowały jej osłabienie. W przypadku zastosowania jako wierzchniej warstwy szelaku złocistego w alkoholu butylowym, występuje bardzo słaba adhezja obu warstw. Wierzchnia warstwa odeszła wraz z taśma podczas badania. Dobrą przyczepność do warstwy Paraloidu B-72 wykazują warstwy Regalrezu 1094 w benzynie lakowej i werniksu Damara Varnish Glossy 081 Talens.

\begin{tabular}{|c|c|c|c|}
\hline \multicolumn{4}{|c|}{$\begin{array}{l}\text { Tabela V. Lakiery dwuwarstwowe - badanie przyczepności (po } 4 \text { miesiącach od nałożenia), } \\
\text { temp } 20^{\circ} \mathrm{C} \text {, wilg. } 30 \%\end{array}$} \\
\hline Lakier - warstwa spodnia & Lakier - warstwa wierzchnia & Wynik & Opis \\
\hline \multirow{7}{*}{$\begin{array}{l}\text { 14\% Laropal A } 81 \text { w [al- } \\
\text { koholu etylowym + DPM } \\
(2: 1) \text { ] } \\
\text { Warunki nakładania } \\
\text { Temp 20C, wilg. } 50 \% \\
\text { Ocena przyczepności poje- } \\
\text { dynczej warstwy: } 1,4\end{array}$} & $\begin{array}{l}\text { Olej Iniany, mastyks, olejek terpen- } \\
\text { tynowy }(1: 1: 1) \\
+ \text { farba olejna Rose Madder } 329 \\
\text { Rembrandt Talens }\end{array}$ & 3,5 & $\begin{array}{l}\text { Powierzchnia błyszcząca. Po oderwaniu taśmy } \\
\text { wierzchnia warstwa bardzo delikatnie matowa. Bar- } \\
\text { dzo dobra adhezja obu warstw (widoczna granica). } \\
\text { Ocena stopnia ubytku dotyczy obu warstw }\end{array}$ \\
\hline & $\begin{array}{l}\text { Kopal z Madagaskaru, olej Iniany, } \\
\text { olejek terpentynowy (2:1:2) } \\
+ \text { farba olejna Indian Yellow } 244 \\
\text { Van Gogh Talens }\end{array}$ & 2,5 & $\begin{array}{l}\text { Powierzchnia błyszcząca. Po oderwaniu taśmy } \\
\text { wierzchnia warstwa bardzo delikatnie matowa. Bar- } \\
\text { dzo dobra adhezja obu warstw (widoczna granica). } \\
\text { Ocena stopnia ubytku dotyczy obu warstw }\end{array}$ \\
\hline & $\begin{array}{l}\text { Acrylic Varnish Glossy } 114 \text { Talens } \\
+ \text { farba olejna Indian Yellow } 244 \\
\text { Van Gogh Talens }\end{array}$ & 1,8 & $\begin{array}{l}\text { Powierzchnia błyszcząca. Bardzo dobra adhezja obu } \\
\text { warstw (widoczna granica). Ocena stopnia ubytku } \\
\text { dotyczy obu warstw }\end{array}$ \\
\hline & $\begin{array}{l}\text { Damara Varnish Glossy } 081 \text { Ta- } \\
\text { lens + farba olejna Phthalo Blue } \\
570 \text { Rembrandt Talens }\end{array}$ & 2,5 & $\begin{array}{l}\text { Powierzchnia błyszcząca. Po oderwaniu taśmy } \\
\text { wierzchnia warstwa delikatnie matowa. Bardzo do- } \\
\text { bra adhezja między warstwami (widoczna granica). } \\
\text { Ocena stopnia ubytku dotyczy obu warstw }\end{array}$ \\
\hline & $\begin{array}{l}\text { Decorfin Glass Yellow } 200 \text { Talens } \\
+ \text { white spirit D } 40(2: 1)\end{array}$ & 3,5 & $\begin{array}{l}\text { Powierzchnia błyszcząca. Bardzo dobra adhezja } \\
\text { między warstwami (widoczna granica). Ocena stop- } \\
\text { nia ubytku dotyczy obu warstw }\end{array}$ \\
\hline & $\begin{array}{l}\text { Damara, olej Iniany, olejek terpen- } \\
\text { tynowy }(2: 3: 3)+\text { farba olejna In- } \\
\text { dian Yellow } 244\end{array}$ & 1,4 & $\begin{array}{l}\text { Powierzchnia błyszcząca. Bardzo dobra adhezja obu } \\
\text { warstw (widoczna granica). Ocena stopnia ubytku } \\
\text { dotyczy obu warstw }\end{array}$ \\
\hline & $\begin{array}{l}\text { Mikstion 3h Lefranc + farba olej- } \\
\text { na Rose Madder } 329 \text { Rembrandt } \\
\text { Talens }\end{array}$ & 0,2 & $\begin{array}{l}\text { Powierzchnia błyszcząca. Bardzo dobra adhezja obu } \\
\text { warstw (widoczna granica). Ocena stopnia ubytku } \\
\text { dotyczy obu warstw }\end{array}$ \\
\hline
\end{tabular}

Warstwa lakieru Laropal A-81 wykazała lepszą przyczepność do wierzchnich warstw niż do podłoża, z tego też powodu ocena powstajacych ubytków dotyczy obu warstw. Stosunkowo dobry rezultat przyniosło naniesienie jako wierzchniej warstwy werniksu Acrylic Varnish Glossy 114 Talens i lakieru olejno-żywicznego (damara, olej lniany, olejek terpentynowy). Najlepszy wynik otrzymano dla warstwy Mikstionu 3h Lefranc. 


\begin{tabular}{|c|c|c|c|}
\hline \multicolumn{4}{|c|}{$\begin{array}{c}\text { Tabela VI. Lakiery dwuwarstwowe - badanie przyczepności (po } 4 \text { miesiącach od nałożenia), } \\
\text { temp } 20^{\circ} \mathrm{C} \text {, wilg. } 30 \%\end{array}$} \\
\hline Lakier - warstwa spodnia & Lakier - warstwa wierzchnia & Wynik & Opis \\
\hline \multirow{17}{*}{$\begin{array}{l}\text { 15\% Szelak bielony w al- } \\
\text { koholu butylowym } \\
\text { Warunki nakładania } \\
\text { Temp 20C, wilg. } 50 \% \\
\text { Ocena przyczepności poje- } \\
\text { dynczej warstwy: 0,2 }\end{array}$} & \multirow{2}{*}{$\begin{array}{l}\text { 20\% Regalrez } 1094 \text { w white spirit } \\
\text { D40 + farba olejna Indian } 244 \text { Yel- } \\
\text { low Van Gogh Talens }\end{array}$} & 1,0 & \multirow{2}{*}{$\begin{array}{l}\text { Powierzchnia warstwy półmatowa. Po oderwaniu ta- } \\
\text { śmy powierzchnia warstwy matowa, część wierzch- } \\
\text { niej warstwy zostało na taśmie. Dobra adhezja obu } \\
\text { warstw (widoczna granica). U góry ocena stopnia } \\
\text { ubytku wierzchniej warstwy, u dołu spodniej } \\
\end{array}$} \\
\hline & & 0,0 & \\
\hline & $\begin{array}{l}\text { 14\% Paraloid B-44 w [toluenie }+ \\
\text { DPM (2:1)] barwnik spirytusowy } \\
\text { Blau } 807 \text { BASF }\end{array}$ & 0,0 & $\begin{array}{l}\text { Powierzchnia błyszcząca. Bardzo dobra adhezja } \\
\text { między warstwami (widoczna granica). Ocena stop- } \\
\text { nia ubytku dotyczy obu warstw }\end{array}$ \\
\hline & $\begin{array}{l}15 \% \text { Szelak złocisty } w \text { alkoholu } \\
\text { butylowym + barwnik spirytusowy } \\
\text { Blau } 807 \text { BASF }\end{array}$ & 1,0 & $\begin{array}{l}\text { Powierzchnia gładka twarda. Bardzo dobra adhezja } \\
\text { między warstwami (brak widocznej granicy). Ocena } \\
\text { stopnia uszkodzenia dotyczy obu warstw }\end{array}$ \\
\hline & $\begin{array}{l}\text { Kopal z Madagaskaru, olej Iniany, } \\
\text { olejek terpentynowy (2:1:2) } \\
+ \text { farba olejna Indian Yellow } 244\end{array}$ & 0,7 & $\begin{array}{l}\text { Powierzchnia lekko błyszcząca. Bardzo dobra ad- } \\
\text { hezja między warstwami (widoczna granica). Ocena } \\
\text { stopnia uszkodzenia dotyczy obu warstw }\end{array}$ \\
\hline & $\begin{array}{l}\text { Acrylic Varnish Glossy } 114 \text { Talens } \\
+ \text { farba olejna Indian Yellow } 244 \\
\text { Van Gogh Talens }\end{array}$ & 0,5 & $\begin{array}{l}\text { Warstwa lekko błyszcząca. Bardzo dobra adhezja } \\
\text { między warstwami (widoczna granica). Ocena stop- } \\
\text { nia uszkodzenia dotyczy obu warstw }\end{array}$ \\
\hline & \multirow{2}{*}{$\begin{array}{l}\text { Damara Varnish Glossy } 081 \text { Ta- } \\
\text { lens + farba olejna Phthalo Blue } \\
570 \text { Rembrandt Talens }\end{array}$} & 2,0 & \multirow{2}{*}{$\begin{array}{l}\text { Warstwa błyszcząca. Po oderwaniu taśmy po- } \\
\text { wierzchnia matowa. Nie odpadają fragment, ale po- } \\
\text { wstaje regularne wykruszenie wzdłuż cięcia. U góry } \\
\text { ocena stopnia ubytku wierzchniej warstwy, u do- } \\
\text { łu spodniej }\end{array}$} \\
\hline & & 0,2 & \\
\hline & \multirow{2}{*}{$\begin{array}{l}\text { Picture Varnish Glossy } 002 \text { Talens } \\
\text { + farba olejna Phthalo Blue Green } \\
576 \text { Rembrandt Talens }\end{array}$} & 1,4 & \multirow{2}{*}{$\begin{array}{l}\text { Powierzchnia błyszcząca. Po oderwaniu taśmy lek- } \\
\text { ko matowa. Nie odpadają fragment, ale powstaje } \\
\text { regularne wykruszenie wzdłuż cięcia, mniejsze niż } \\
\text { w przypadku lakieru damarowego. U góry ocena } \\
\text { stopnia ubytku dotyczy wierzchniej warstwy, u do- } \\
\text { łu spodniej }\end{array}$} \\
\hline & & 0,0 & \\
\hline & $\begin{array}{l}\text { Bernsteinlack echt (Kremer) } \\
+ \text { farba olejna Indian Yellow } 244 \\
\text { Van Gogh Talens }\end{array}$ & 0,6 & $\begin{array}{l}\text { Powierzchnia błyszcząca. Bardzo dobra adhezja } \\
\text { między warstwami (widoczna granica). Ocena stop- } \\
\text { nia uszkodzenia dotyczy obu warstw }\end{array}$ \\
\hline & $\begin{array}{l}\text { Decorfin Glass Blue } 500+501 \text { Ta- } \\
\text { lens + white spirit D } 40(7: 3)\end{array}$ & 0,0 & $\begin{array}{l}\text { Powierzchnia błyszcząca. Bardzo ładny efekt. Bardzo } \\
\text { dobra adhezja między warstwami (widoczna grani- } \\
\text { ca). Ocena stopnia uszkodzenia dotyczy obu warstw }\end{array}$ \\
\hline & Lakier szelakowy blue + DPM (2:1) & 0,0 & $\begin{array}{l}\text { Powierzchnia błyszcząca. Bardzo tadny efekt. Bar- } \\
\text { dzo dobra adhezja między warstwami (brak wyraź- } \\
\text { nej granicy). Ocena stopnia uszkodzenia dotyczy } \\
\text { obu warstw }\end{array}$ \\
\hline & $\begin{array}{l}\text { Incral 44+ barwnik Savinyl Rot } \\
\text { RLSN Clariant }\end{array}$ & 0,0 & $\begin{array}{l}\text { Powierzchnia błyszcząca. Bardzo ładny efekt. Bar- } \\
\text { dzo dobra adhezja między warstwami (brak wyraź- } \\
\text { nej granicy). Ocena stopnia uszkodzenia dotyczy } \\
\text { obu warstw }\end{array}$ \\
\hline & $\begin{array}{l}\text { Damara, olej Iniany, olejek terpen- } \\
\text { tynowy (2:3:3) + farba olejna In- } \\
\text { dian Yellow } 244\end{array}$ & 0,4 & $\begin{array}{l}\text { Powierzchnia błyszczaca. Bardzo dobra adhezja } \\
\text { między warstwami (widoczna granica). Ocena stop- } \\
\text { nia uszkodzenia dotyczy obu warstw }\end{array}$ \\
\hline & $\begin{array}{l}\text { Mastyks, olej Iniany, olejek ter- } \\
\text { pentynowy }(2: 3: 3)+\text { farba olejna } \\
\text { Indian Yellow } 244\end{array}$ & 0,3 & $\begin{array}{l}\text { Powierzchnia lekko błyszcząca. Bardzo dobra ad- } \\
\text { hezja między warstwami (widoczna granica). Ocena } \\
\text { stopnia uszkodzenia dotyczy obu warstw }\end{array}$ \\
\hline & $\begin{array}{l}\text { Damara, olej Iniany, olejek terpen- } \\
\text { tynowy (2:3:3) + farba olejna In- } \\
\text { dian Yellow } 244\end{array}$ & 0,6 & $\begin{array}{l}\text { Powierzchnia błyszczaca. Bardzo dobra adhezja } \\
\text { między warstwami (widoczna granica). Ocena stop- } \\
\text { nia uszkodzenia dotyczy obu warstw }\end{array}$ \\
\hline
\end{tabular}


Bardzo dobry efekt dało użycie jako spodniej warstwy szelaku bielonego w alkoholu butylowym. Warstwy wierzchnie charakteryzowała bardzo dobra przyczepność do warstwy szelaku, ona zaś nie utraciła jej w stosunku do podłoża. Najlepsze rezultaty osiagnięto z Paraloidem B-44 w toluenie z dodatkiem DPM (2:1), farbami do szkła Decorfin Glass Talens i lakierem Incral 44, gdzie ocena uszkodzenia wyniosła 0. Najsłabsza przyczepność do warstwy szelaku wykazały werniksy Dammar Varnish Glossy 081 Talens i Picture Varnish Glossy 002 Talens.

\begin{tabular}{|c|c|c|c|}
\hline \multicolumn{4}{|c|}{$\begin{array}{l}\text { Tabela VII. Lakiery dwuwarstwowe - badanie przyczepności (po } 4 \text { miesiącach od nałożenia), } \\
\text { temp 200 } 2 \text {, wilg. } 30 \%\end{array}$} \\
\hline Lakier - warstwa spodnia & Lakier - warstwa wierzchnia & Wynik & $\begin{array}{c}\text { Opis } \\
\end{array}$ \\
\hline \multirow{17}{*}{$\begin{array}{l}\text { 20\% Szelak bielony w me- } \\
\text { toksy-2-propanolu + barw- } \\
\text { nik Blau } 807 \text { BASF } \\
\text { Warunki nakładania } \\
\text { Temp 20C, wilg. 50\% } \\
\text { Ocena przyczepności poje- } \\
\text { dynczej warstwy: 0,3 }\end{array}$} & $\begin{array}{l}\text { 20\% Regalrez } 1094 \text { w white spirit } \\
\text { D40 + farba olejna Indian Yellow } \\
244 \text { Van Gogh Talens }\end{array}$ & 0,4 & $\begin{array}{l}\text { Powierzchnia półmatowa, po oderwaniu taśmy ma- } \\
\text { towa. Drobiny wierzchniej warstwy pozostają na ta- } \\
\text { śmie. Ocena stopnia ubytku dotyczy obu warstw }\end{array}$ \\
\hline & $\begin{array}{l}\text { 14\% Paraloid B-44 w [toluenie }+ \\
\text { DPM }(2: 1)]+ \text { barwnik Blau } 807 \\
\text { BASF }\end{array}$ & 0,3 & $\begin{array}{l}\text { W trakcie długiego nanoszenia rozpuszcza spodnią } \\
\text { warstwę. Warstwa błyszcząca. Bardzo dobra adhezja } \\
\text { między warstwami (widoczna granica). Ocena stop- } \\
\text { nia ubytku dotyczy obu warstw }\end{array}$ \\
\hline & $\begin{array}{l}\text { 15\% Szelak złocisty (nieodwosk.) } \\
\text { w alkoholu butylowym + barwnik } \\
\text { Blau } 807 \text { BASF }\end{array}$ & 0,0 & $\begin{array}{l}\text { Warstwa lekko błyszcząca. Bardzo dobra adhezja } \\
\text { między warstwami (brak wyraźnej granicy). Ocena } \\
\text { stopnia ubytku dotyczy obu warstw }\end{array}$ \\
\hline & \multirow{2}{*}{\begin{tabular}{|l|} 
Olej Iniany, mastyks, olejek terpen- \\
tynowy $(1: 1: 1)$ + farba olejna Rose \\
Madder 329 \\
\end{tabular}} & 2,7 & \multirow{2}{*}{\begin{tabular}{|l|} 
Warstwa błyszcząca. U góry ocena stopnia ubytk \\
wierzchniej warstwy, u dołu uszkodzenia spodniej \\
Bardzo dobra przyczepność spodniej warstwy
\end{tabular}} \\
\hline & & 0,2 & \\
\hline & \multirow{2}{*}{\begin{tabular}{|l|} 
Kopal z Madagaskaru, olej Iniany, \\
olejek terpentynowy (2:1:2) + farba \\
olejna Indian Yellow 244
\end{tabular}} & 1,1 & \multirow{2}{*}{$\begin{array}{l}\text { Warstwa błyszczacca. U góry ocena stopnia ubytkl } \\
\text { wierzchniej warstwy, u dołu uszkodzenia spodniej } \\
\text { Bardzo dobra przyczepność spodniej warstwy }\end{array}$} \\
\hline & & 0,1 & \\
\hline & \multirow{2}{*}{$\begin{array}{l}\text { Acrylic Varnish Glossy } 114 \text { Talens } \\
+ \text { farba olejna Indian Yellow } 244 \\
\text { Van Gogh Talens }\end{array}$} & 2,8 & \multirow{2}{*}{$\begin{array}{l}\text { Warstwa lekko błyszcząca. U góry ocena stop } \\
\text { nia ubytku wierzchniej warstwy, u dołu uszkodze } \\
\text { nia spodniej. Bardzo dobra przyczepność spodnie } \\
\text { warstwy }\end{array}$} \\
\hline & & 0,3 & \\
\hline & \multirow{2}{*}{$\begin{array}{l}\text { Damara Varnish Glossy 081, } \mathrm{T}+ \\
\text { farba olejna Phthalo Blue } 570\end{array}$} & 2,5 & \multirow{2}{*}{$\begin{array}{l}\text { Warstwa błyszcząca. Po oderwaniu taśmy warstwa } \\
\text { zmatowiona. U góry ocena stopnia ubytku wierzch- } \\
\text { niej warstwy, u dołu uszkodzenia spodniej. Bardzo } \\
\text { dobra przyczepność spodniej warstwy }\end{array}$} \\
\hline & & 0,2 & \\
\hline & \multirow{2}{*}{$\begin{array}{l}\text { Picture Varnish Glossy } 002 \text { Talens } \\
\text { + farba olejna Phthalo Blue Green } \\
576 \text { Rembrandt, Talens }\end{array}$} & 2,4 & \multirow{2}{*}{$\begin{array}{l}\text { Warstwa błyszcząca. Po oderwaniu taśmy warstwa } \\
\text { zmatowiona. U góry ocena stopnia ubytku wierzch- } \\
\text { niej warstwy, u dołu uszkodzenia spodniej. Bardzo } \\
\text { dobra przyczepność spodniej warstwy }\end{array}$} \\
\hline & & 0,3 & \\
\hline & $\begin{array}{l}\text { Bernsteinlack echt Kremer }+ \text { far- } \\
\text { ba olejna Rose Madder Rembrandt } \\
\text { Talens }\end{array}$ & 0,0 & $\begin{array}{l}\text { Warstwa błyszcząca. Bardzo dobra adhezja między } \\
\text { warstwami (widoczna granica). Ocena stopnia ubyt- } \\
\text { ku dotyczy obu warstw. Bardzo dobry efekt }\end{array}$ \\
\hline & $\begin{array}{l}\text { Decorfin Glass Red } 300 \text { Talens + } \\
\text { white spirit D40 (2:1) }\end{array}$ & 0,3 & $\begin{array}{l}\text { Warstwa błyszcząca. Bardzo dobra adhezja między } \\
\text { warstwami (widoczna granica). Ocena stopnia ubyt- } \\
\text { ku dotyczy obu warstw. Bardzo dobry efekt }\end{array}$ \\
\hline & \multirow{2}{*}{$\begin{array}{l}\text { Damara, olej Iniany, olejek terpen- } \\
\text { tynowy (2:3:3) + farba olejna In- } \\
\text { dian Yellow } 244\end{array}$} & 2,1 & \multirow{2}{*}{$\begin{array}{l}\text { Warstwa błyszcząca. U góry ocena stopnia ubyt- } \\
\text { ku dotyczy wierzchniej warstwy, u dołu uszkodze- } \\
\text { nia spodniej. Bardzo dobra przyczepność spodniej } \\
\text { warstwy }\end{array}$} \\
\hline & & 0,3 & \\
\hline
\end{tabular}


Zbliżone rezultaty do wyników badania powłok szelaku bielonego rozpuszczonego w alkoholu butylowym uzyskano przy badaniu przyczepności powłok szelaku bielonego rozpuszczonego w 1-metoksy-2-propanolu. Bardzo dobra przyczepność do warstwy szelaku wykazywał Paraloid B-44 w toluenie z dodatkiem DPM (2:1), farba do szkła Decorfin Glass Talens, lakier Bernsteinlack echt Kremer, a także żywica Regalrez 1094 w white spirit. Nieco słabsza była przyczepność do warstwy szelaku werniksów: Acrylic Varnish Picture Glossy 114 Talens, Damara Varnish Glossy 081 Talens i Picture Varnish Glossy 002 Talens. 


\begin{tabular}{|c|c|c|c|}
\hline \multicolumn{4}{|c|}{$\begin{array}{l}\text { Tabela VIII. Lakiery dwuwarstwowe - badanie przyczepności (po } 4 \text { miesiącach od nałożenia), } \\
\text { temp 200 } 2 \text {, wilg. } 30 \%\end{array}$} \\
\hline Lakier - warstwa spodnia & Lakier - warstwa wierzchnia & Wynik & Opis \\
\hline \multirow{13}{*}{$\begin{array}{l}15 \% \text { Sandarak w alkoholu } \\
\text { butylowym + barwnik Savi- } \\
\text { nyl Gelb RLSN Clariant } \\
\text { Warunki nakładania } \\
\text { Temp 20C, wilg. } 50 \% \\
\\
\text { Ocena przyczepności poje- } \\
\text { dynczej warstwy: } 1,3\end{array}$} & $\begin{array}{l}\text { 20\% Regalrez } 1094 \text { w white spirit } \\
\text { D40 + farba olejna Indian Yellow } \\
\text { Van Gogh Talens }\end{array}$ & 2,0 & $\begin{array}{l}\text { Powierzchnia półmatowa. Po oderwaniu taśmy ma- } \\
\text { towa. Drobiny wierzchniej warstwy zostało na ta- } \\
\text { śmie. U góry ocena stopnia ubytku wierzchniej } \\
\text { warstwy, u dołu spodniej }\end{array}$ \\
\hline & $\begin{array}{l}\text { Olej Iniany, mastyks, olejek terpen- } \\
\text { tynowy }(1: 1: 1)+\text { farba olejna Rose } \\
\text { Madder } 329\end{array}$ & 4,3 & $\begin{array}{l}\text { Powierzchnia błyszcząca. Dobra adhezja mię- } \\
\text { dzy warstwami (widoczna granica). Ocena stopnia } \\
\text { uszkodzenia dotyczy obu warstw }\end{array}$ \\
\hline & $\begin{array}{l}\text { Kopal z Madagaskaru, olej Iniany, } \\
\text { olejek terpentynowy (2:1:2) + farba } \\
\text { olejna Indian Yellow } 244\end{array}$ & 3,3 & $\begin{array}{l}\text { Powierzchnia błyszcząca. Dobra adhezja mię- } \\
\text { dzy warstwami (widoczna granica). Ocena stopnia } \\
\text { uszkodzenia dotyczy obu warstw }\end{array}$ \\
\hline & $\begin{array}{l}\text { Acrylic Varnish Glossy } 114 \text { Talens } \\
\text { + farba olejna Indian Yellow } 244 \\
\text { Van Gogh Talens }\end{array}$ & 1,8 & $\begin{array}{l}\text { Powierzchnia lekko błyszcząca. U góry ocena stop- } \\
\text { nia ubytku dotyczy wierzchniej warstwy, u dołu } \\
\text { spodniej }\end{array}$ \\
\hline & $\begin{array}{l}\text { Damara Varnish Glossy } 081 \text { Ta- } \\
\text { lens + farba olejna Phthalo Blue } \\
570 \text { Rembrandt Talens }\end{array}$ & 2,0 & $\begin{array}{l}\text { Powierzchnia błyszcząca. Po oderwaniu taśmy lekko } \\
\text { matowa. Dobra adhezja między warstwami (widocz- } \\
\text { na granica). Ocena stopnia uszkodzenia dotyczy } \\
\text { obu warstw }\end{array}$ \\
\hline & \multirow{2}{*}{$\begin{array}{l}\text { Picture Varnish Glossy } 002 \text { Talens } \\
\text { + farba olejna Phthalo Blue Green } \\
576 \text { Rembrandt, Talens }\end{array}$} & 2,2 & \multirow{2}{*}{$\begin{array}{l}\text { Powierzchnia błyszcząca. Po oderwaniu taśmy ma- } \\
\text { towa. U góry ocena stopnia ubytku wierzchniej war- } \\
\text { stwy, u dołu spodniej }\end{array}$} \\
\hline & & 1,1 & \\
\hline & $\begin{array}{l}\text { Bernsteinlack echt (Kremer) + farba } \\
\text { olejna Indian Yellow 244, Van } \\
\text { Gogh Talens (10:1) }\end{array}$ & 1,1 & $\begin{array}{l}\text { Powierzchnia błyszcząca. U góry ocena stop- } \\
\text { nia ubytku dotyczy wierzchniej warstwy, u dołu } \\
\text { spodniej }\end{array}$ \\
\hline & $\begin{array}{l}\text { Decorfin Glass Blue } 500+501 \text { Ta- } \\
\text { lens + white spirit D } 40(7: 3)\end{array}$ & 2,8 & $\begin{array}{l}\text { Powierzchnia błyszcząca. Dobra adhezja mię- } \\
\text { dzy warstwami (widoczna granica). Ocena stopnia } \\
\text { uszkodzenia dotyczy obu warstw }\end{array}$ \\
\hline & $\begin{array}{l}\text { Damara, olej Iniany, olejek terpen- } \\
\text { tynowy (2:3:3) + farba olejna In- } \\
\text { dian Yellow } 244\end{array}$ & 3,9 & $\begin{array}{l}\text { Powierzchnia błyszcząca. U góry ocena stop- } \\
\text { nia ubytku dotyczy wierzchniej warstwy, u dołu } \\
\text { spodniej }\end{array}$ \\
\hline & $\begin{array}{l}\text { 20\% Szelak bielony w 1-metoksy- } \\
\text {-2-propanolu + barwnik Blau } 807 \\
\text { BASF }\end{array}$ & 0,0 & $\begin{array}{l}\text { Powierzchnia błyszcząca. Bardzo dobra adhezja } \\
\text { między warstwami (brak wyraźnej granicy). Ocena } \\
\text { stopnia uszkodzenia dotyczy obu warstw }\end{array}$ \\
\hline & \multirow{2}{*}{$\begin{array}{l}\text { Mikstion 3h Lefranc + farba olej- } \\
\text { na Indian Yellow } 244 \text { Van Gogh } \\
\text { Talens }\end{array}$} & 3,0 & \multirow{2}{*}{$\begin{array}{l}\text { Powierzchnia błyszcząca. W fragmentach widocz- } \\
\text { ne czéściowe oderwanie się warstwy wierzchniej } \\
\text { od spodniej. U góry ocena stopnia ubytku dotyczy } \\
\text { wierzchniej warstwy, u dołu spodniej }\end{array}$} \\
\hline & & 2,7 & \\
\hline
\end{tabular}


Znacznie gorszy wynik uzyskano, stosując jako spodnią warstwę sandarak w alkoholu butylowym, ze względu na znacznie mniejszą przyczepność tej żywicy do metalowej płytki, wynosząca 1,3-1,5. Niezadowalające efekty przyniosło użycie jako wierzchnich warstw lakierów olejno-żywicznych, które w znacznym stopniu osłabiły adhezję warstwy sandaraku do podłoża. Dużo lepiej wypadły werniksy Acrylic Varnish Glossy 114 Talens, Dammar Varnish Glossy 081, Picture Varnish Glossy 002 Talens, które w niewielkim stopniu wpłynęły na przyczepność warstwy spodniej do podłoża. Doskonały rezultat uzyskano po naniesieniu jako wierzchniej warstwy szelaku bielonego w 1-metoksy-2-propanolu, gdyż warstwa wierzchnia rozpuściła spodnią i powstała powłoka o stopniu przyczepności charakterystycznym dla szelaku. Zbliżone rezultaty otrzymano, wykorzystując jako spodnią warstwę sandarak w alkoholu etylowym z dodatkiem DPM (2:1). 


\begin{tabular}{|c|c|c|c|}
\hline \multicolumn{4}{|c|}{$\begin{array}{l}\text { Tabela IX. Lakiery dwuwarstwowe - badanie przyczepności (po } 4 \text { miesiącach od nałożenia), } \\
\text { temp } 20^{\circ} \mathrm{C} \text {, wilg. } 30 \%\end{array}$} \\
\hline Lakier - warstwa spodnia & Lakier - warstwa wierzchnia & Wynik & Opis \\
\hline \multirow[t]{2}{*}{$\begin{array}{l}15 \% \text { Sandarak w [alkoho- } \\
\text { lu etylowym + DPM (2:1)] } \\
+ \text { barwnik Savinyl Gelb } \\
\text { RLSN Clariant }\end{array}$} & $\begin{array}{l}20 \% \text { Regalrez } 1094 \text { w white spirit } \\
\text { D40 + farba olejna Indian Yellow } \\
\text { Van Gogh Talens }\end{array}$ & 0,3 & $\begin{array}{l}\text { Powierzchnia półmatowa. Po oderwaniu taśmy ma- } \\
\text { towa, drobiny wierzchniej warstwy zostały na ta- } \\
\text { śmie. U góry ocena stopnia ubytku wierzchniej } \\
\text { warstwy, u dołu spodniej }\end{array}$ \\
\hline & $\begin{array}{l}\text { Olej Iniany, mastyks, olejek terpen- } \\
\text { tynowy }(1: 1: 1)+\text { farba olejna Rose } \\
\text { Madder } 329\end{array}$ & 3,8 & $\begin{array}{l}\text { Powierzchnia błyszcząca. Dobra adhezja mię- } \\
\text { dzy warstwami (widoczna granica). Ocena stopnia } \\
\text { uszkodzenia dotyczy obu warstw }\end{array}$ \\
\hline \multirow[t]{13}{*}{$\begin{array}{l}\text { Ocena przyczepności poje- } \\
\text { dynczej warstwy: } 1,3\end{array}$} & $\begin{array}{l}\text { Kopal z Madagaskaru, olej Iniany, } \\
\text { olejek terpentynowy (2:1:2) + farba } \\
\text { olejna Indian Yellow } 244\end{array}$ & 3,5 & $\begin{array}{l}\text { Powierzchnia błyszcząca. Dobra adhezja mię- } \\
\text { dzy warstwami (widoczna granica). Ocena stopnia } \\
\text { uszkodzenia dotyczy obu warstw }\end{array}$ \\
\hline & \multirow{2}{*}{$\begin{array}{l}\text { Acrylic Varnish Glossy } 114 \text { Talens } \\
+ \text { farba olejna Indian Yellow } 244 \\
\text { Van Gogh Talens }\end{array}$} & 2,0 & \multirow{2}{*}{$\begin{array}{l}\text { Powierzchnia błyszcząca. U góry ocena stopnia } \\
\text { ubytku wierzchniej warstwy, u dołu spodniej }\end{array}$} \\
\hline & & 1,2 & \\
\hline & $\begin{array}{l}\text { Damara Varnish Glossy } 081 \text { Ta- } \\
\text { lens + farba olejna Phthalo Blue } \\
570 \text { Rembrandt Talens }\end{array}$ & 2,0 & $\begin{array}{l}\text { Powierzchnia błyszcząca po oderwaniu taśmy ma- } \\
\text { towa. Dobra adhezja miedzy warstwami (widoczna } \\
\text { granica). Ocena stopnia uszkodzenia dotyczy obu } \\
\text { warstw }\end{array}$ \\
\hline & \multirow{2}{*}{$\begin{array}{l}\text { Picture Varnish Glossy } 002 \text { Talens } \\
\text { + farba olejna Phthalo Blue Green } \\
576 \text { Rembrandt Talens }\end{array}$} & 1,3 & \multirow{2}{*}{$\begin{array}{l}\text { Powierzchnia błyszcząca po oderwaniu taśmy mato- } \\
\text { wa. U góry ocena stopnia ubytku wierzchniej war- } \\
\text { stwy, u dołu spodniej }\end{array}$} \\
\hline & & 0,3 & \\
\hline & \multirow{2}{*}{$\begin{array}{l}\text { Bernsteinlack echt Kremer + farba } \\
\text { olejna Indian Yellow } 244 \text { Van } \\
\text { Gogh Talens }\end{array}$} & 2,2 & \multirow{2}{*}{$\begin{array}{l}\text { Powierzchnia błyszcząca. Po oderwaniu taśmy bez } \\
\text { zmian. U góry ocena stopnia ubytku wierzchniej } \\
\text { warstwy, u dołu spodniej }\end{array}$} \\
\hline & & 1,2 & \\
\hline & \multirow{2}{*}{$\begin{array}{l}\text { Decorfin Glass Blue } 500+501 \text { Ta- } \\
\text { lens + white spirit D } 40(2: 1)\end{array}$} & 2,7 & \multirow{2}{*}{$\begin{array}{l}\text { Powierzchnia błyszcząca. U góry ocena stop- } \\
\text { nia ubytku wierzchniej warstwy, u dołu spodniej. } \\
\text { Spodnia warstwa - mikrospękania }\end{array}$} \\
\hline & & 1,3 & \\
\hline & $\begin{array}{l}\text { Damara, olej Iniany, olejek terpen- } \\
\text { tynowy }(2: 3: 3)+\text { farba olejna In- } \\
\text { dian Yellow } 244\end{array}$ & 2,1 & $\begin{array}{l}\text { Powierzchnia błyszcząca. Dobra adhezja mię- } \\
\text { dzy warstwami (widoczna granica). Ocena stopnia } \\
\text { uszkodzenia dotyczy obu warstw }\end{array}$ \\
\hline & $\begin{array}{l}\text { 20\% Szelak bielony w 1-metoksy- } \\
-2-\text { propanolu + barwnik Blau } 807 \\
\text { BASF }\end{array}$ & 0,0 & $\begin{array}{l}\text { Powierzchnia błyszcząca. Bardzo dobry efekt! Bar- } \\
\text { dzo dobra adhezja między warstwami (brak wyraź- } \\
\text { nej granicy). Ocena stopnia uszkodzenia dotyczy } \\
\text { obu warstw }\end{array}$ \\
\hline & $\begin{array}{l}\text { Mikstion 3h Lefranc + farba olej- } \\
\text { na Indian Yellow Van Gogh Talens }\end{array}$ & 3,0 & $\begin{array}{l}\text { Powierzchnia błyszcząca. Dobra adhezja mie- } \\
\text { dzy warstwami (widoczna granica). Ocena stopnia } \\
\text { uszkodzenia dotyczy obu warstw }\end{array}$ \\
\hline
\end{tabular}

Analogiczne rezultaty do Sandaraku w alkoholu butylowym uzyskano z zastosowanie jako spodniej warstwy sandaraku rozpuszczonego w alkoholu etylowym z dodatkiem DPM (2:1). 


\begin{tabular}{|c|c|c|c|}
\hline \multicolumn{4}{|c|}{$\begin{array}{l}\text { Tabela X. Lakiery dwuwarstwowe - badanie przyczepności (po } 4 \text { miesiącach od nałożenia), } \\
\text { temp } 20^{\circ} \mathrm{C} \text {, wilg. } 30 \%\end{array}$} \\
\hline Lakier - warstwa spodnia & Lakier - warstwa wierzchnia & Wynik & Opis \\
\hline \multirow[t]{2}{*}{$\begin{array}{l}\text { Lakier mastyksowo-olejny } \\
\text { (sykatywowany) w olejku } \\
\text { terpentynowym }\end{array}$} & $\begin{array}{l}\text { Acrylic Varnish Glossy } 114 \text { Talens } \\
+ \text { farba olejna Indian Yellow } 244 \\
\text { Van Gogh Talens }\end{array}$ & 3,5 & $\begin{array}{l}\text { Powierzchnia błyszcząca. Dobra adhezja mię- } \\
\text { dzy warstwami (widoczna granica). Ocena stopnia } \\
\text { uszkodzenia dotyczy obu warstw }\end{array}$ \\
\hline & $\begin{array}{l}\text { Damara Varnish Glossy } 081 \text { Ta- } \\
\text { lens + farba olejna Phthalo Blue } \\
570 \text { Rembrandt Talens }\end{array}$ & 4,2 & $\begin{array}{l}\text { Powierzchnia błyszcząca, po oderwaniu taśmy ma- } \\
\text { towa. Dobra adhezja między warstwami (widoczna } \\
\text { granica). Ocena stopnia uszkodzenia dotyczy obu } \\
\text { warstw }\end{array}$ \\
\hline \multirow[t]{5}{*}{$\begin{array}{l}\text { Ocena przyczepności poje- } \\
\text { dynczej warstwy: } 3,5\end{array}$} & $\begin{array}{l}\text { Picture Varnish Glossy } 002 \text { Talens } \\
\text { + farba olejna Phthalo Blue Gren } \\
576 \text { Rembrandt Talens }\end{array}$ & 3,5 & $\begin{array}{l}\text { Powierzchnia błyszcząca, po oderwaniu taśmy lek- } \\
\text { ko matowa. Dobra adhezja obu warstw (widoczna } \\
\text { granica). Ocena stopnia uszkodzenia dotyczy obu } \\
\text { warstw }\end{array}$ \\
\hline & $\begin{array}{l}\text { Bernsteinlack echt Kremer }+ \text { far- } \\
\text { ba olejna Rose Madder } 329 \text { Rem- } \\
\text { brandt Talens }\end{array}$ & 3,9 & $\begin{array}{l}\text { Powierzchnia błyszcząca. Dobra adhezja mię- } \\
\text { dzy warstwami (widoczna granica). Ocena stopnia } \\
\text { uszkodzenia dotyczy obu warstw }\end{array}$ \\
\hline & $\begin{array}{l}\text { Decorfin Glass Red } 300 \text { Talens + } \\
\text { white spirit D } 40(7: 3)\end{array}$ & 4,3 & $\begin{array}{l}\text { Powierzchnia błyszcząca. Dobra adhezja mię- } \\
\text { dzy warstwami (widoczna granica). Ocena stopnia } \\
\text { uszkodzenia dotyczy obu warstw }\end{array}$ \\
\hline & $\begin{array}{l}\text { Damara, olej Iniany, olejek terpen- } \\
\text { tynowy }(2: 3: 3)+\text { farba olejna In- } \\
\text { dian Yellow } 244\end{array}$ & 5,0 & $\begin{array}{l}\text { Powierzchnia błyszcząca. Pozostają drobne czą- } \\
\text { steczki lakieru. Dobra adhezja między warstwa- } \\
\text { mi (widoczna granica). Ocena stopnia uszkodzenia } \\
\text { dotyczy obu warstw }\end{array}$ \\
\hline & $\begin{array}{l}\text { Mikstion 3h Lefranc + farba olej- } \\
\text { na Rose Madder } 329 \text { Rembrandt } \\
\text { Talens }\end{array}$ & 4,5 & $\begin{array}{l}\text { Powierzchnia błyszcząca. Pozostają drobne czą- } \\
\text { steczki lakieru. Dobra adhezja między warstwa- } \\
\text { mi (widoczna granica). Ocena stopnia uszkodzenia } \\
\text { dotyczy obu warstw }\end{array}$ \\
\hline
\end{tabular}

Przeprowadzone próby zastosowania jako warstwy spodniej lakieru mastyksowo-olejnego przyniosło negatywne efekty. Przyczepność w przypadku warstwy lakieru mastyksowo-olejnego po naniesieniu warstwy innego lakieru w większości przypadków zmalała. Wyjątek stanowią tu werniksy: Acrylic Varnish Picture Glossy 114 Talens i Picture Varnish Glossy 002 Talens, które nie miały wpływu na jej przyczepność. 


\begin{tabular}{|l|l|c|l|}
\hline \multicolumn{5}{|c|}{ Tabela XI. Lakiery dwuwarstwowe - badanie przyczepności (po 4 miesiącach od nałożenia), } \\
temp 20C, wilg. 30\%
\end{tabular}

Nieco lepsze ocenę przyczepności od lakieru mastyksowo-olejnego uzyskano z powłoka lakieru kopalowo-olejnego. Powłoki obu lakierów w układzie jednowarstwowym maja stosunkowo słaba przyczepność do powierzchni metalu (lakier mastyksowo-olejny - 3,5; lakier kopalowo-olejny $-3,2)$. 
Tabela XII. Lakiery dwuwarstwowe - badanie przyczepności (po 4 miesiącach od nałożenia), temp 20ㄷ, wilg. 30\%

\begin{tabular}{c|c|c|c|}
\hline $\begin{array}{c}\text { Lakier } \\
\text { - warstwa spodnia }\end{array}$ & Lakier - warstwa wierzchnia & Wynik & Opis \\
\hline
\end{tabular}

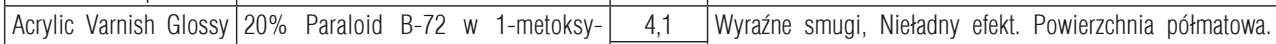

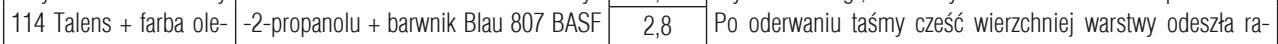
jna Indian Yellow 244 Van Gogh Talens

Warunki nakładania

Temp 20C, wilg. 50\%

Ocena przyczepności pojedynczej warstwy: 0,7

\begin{tabular}{l} 
11\% Paraloid B-48N w [acetonie + \\
DPM (1:1)] + barwnik Savinyl Rot \\
RLSN Clariant \\
\hline $15 \%$ Szelak bielony w alkoholu etylo- \\
wym + barwnik Savinyl Rot RLSN Cla- \\
riant
\end{tabular}

15\% Szelak złocisty w alkoholu butylowym] + barwnik spirytusowy Blau 807 BASF 807 BASF

14\% Szelak bielony w [alkoholu etylowym + DPM (2:1)] + barwnik spirytusowy Blau 807 BASF

14\% Szelak złocisty (nieodwosk.) w [alkoholu etylowym + DPM (2:1)] + barwnik Blau 807 BASF

Olej Iniany, mastyks, olejek terpentynowy (1:1:1) + farba olejna Rose Madder 329

Kopal z Madagaskaru, olej Iniany, olejek terpentynowy (2:1:2) + farba olejna Indian Yellow 244

Damara Varnish Glossy 081 Talens + farba olejna Phthalo Blue 570 Rembrandt Talens

Picture Varnish Glossy 002 Talens + farba olejna Phthalo Blue Green 576 Rembrandt Talens

Bernsteinlack echt Kremer + farba olejna Indian Yellow 244 Van Gogh Talens

\begin{tabular}{|c|c|}
\hline & \\
\hline & 1,0 \\
\hline \multirow{2}{*}{$\begin{array}{l}\text { Decorfin Glass } 500+501 \text { Talens + } \\
\text { white spirit D } 40(7: 3)\end{array}$} & 5,0 \\
\hline & 3,3 \\
\hline \multirow[t]{2}{*}{ Lakier szelakowy (blue) + DPM (2:1) } & 5,0 \\
\hline & 1,4 \\
\hline $\begin{array}{l}\text { Lustrina Restaurarte + DPM (2:1) + } \\
\text { barwnik Savinyl Gelb RLSN Clariant }\end{array}$ & 2,5 \\
\hline
\end{tabular}

Idea Vetro Rose 202 Maimeri + DPM (3:1)

Damara, olej Iniany, olejek terpentynowy (2:3:3) + farba olejna Indian Yellow 244 Van Gogh Talens

2,6 czy obu warstw zem z nią. U góry
u dołu spodniej u dołu spodnie

2,3
wierzchniej warstwy odeszła razem z nią. U góry ocena stopnia ubytku wierzchniej warstwy, u dołu spodniej

4,8 $\quad$ Powierzchnia błyszcząca. Przy odrywaniu taśmy odeszła w całości wierzchnia warstwa w jednej z płytek w drugiej w dużym 2,8 stopniu. U góry ocena stopnia ubytku wierzchniej warstwy, u dołu spodniej

1,4 Powierzchnia półmatowa. Przy odrywaniu taśmy odeszła w niewielkich fragmentach wierzchnia warstwa. Wierzchnia warstwa twarda spodnia miękka (brak wyraźnego podziału na warstwy). Ocena dotyczy stopnia uszkodzenia obu warstw

5,0 $\quad$ Powierzchnia lekko błyszcząca. Przy odrywaniu taśmy odeszła 2,8 wierzchnia warstwa. U góry ocena stopnia ubytku wierzchniej warstwy, u dołu spodniej

5,0 Powierzchnia lekko błyszcząca. Przy odrywaniu taśmy odeszła 2,3

3,8 Powierzchnia błyszcząca. Dobra adhezja miedzy warstwami (widoczna granica). Ocena stopnia uszkodzenia dotyczy obu warstw

2,4 Powierzchnia błyszcząca. Dobra adhezja między warstwami (widoczna granica). Ocena stopnia uszkodzenia dotyczy obu warstw

3,1 Powierzchnia błyszcząca, po oderwaniu taśmy matowa. Dobra adhezja między warstwami (widoczna granica). Ocena stopnia uszkodzenia dotyczy obu warstw

0,4 Powierzchnia błyszcząca, po oderwaniu taśmy matowa. Dobra adhezja między warstwami (widoczna granica). Ocena stopnia uszkodzenia dotyczy obu warstw

4,4 Powierzchnia błyszcząca. Przy odrywaniu taśmy odeszła w dużym stopniu wierzchnia warstwa. U góry ocena stopnia ubytku wierzchniej warstwy, u dołu spodniej

Źle się rozprowadza olejek powoduje rozpuszczanie spodniej warstwy. Powierzchnia błyszcząca. Przy odrywaniu taśmy odeszła w całości wierzchnia warstwa. U góry ocena stopnia ubytku wierzchniej warstwy, u dołu spodniej

Powierzchnia błyszcząca. Przy odrywaniu taśmy odeszła w całości wierzchnia warstwa. U góry ocena dotyczy stopnia ubytku wierzchniej warstwy, u dołu spodniej

Powierzchnia błyszcząca. Bardzo dobra adhezja między warstwami (brak wyraźnej granicy). Ocena stopnia ubytku dotyPowierzchnia błyszcząca. Bardzo dobra adhezja między warstwami (widoczna granica). Ocena stopnia ubytku dotyczy obu warstw

2,3

Olejek terpentynowy powoduje pomarszczenie spodniej warstwy. Powierzchnia lekko błyszcząca. Bardzo dobra adhezja między warstwami (brak wyraźnej granica). Ocena stopnia uszkodzenia ubytku dotyczy obu warstw

\begin{tabular}{lll}
\hline $20 \%$ & Szelak bielony w 1-metoksy- & 5,0 \\
\hline
\end{tabular} -2-propanolu + barwnik Blau 807 BASF

Powierzchnia lekko błyszcząca. Przy odrywaniu taśmy odeszła w całości wierzchnia warstwa. U góry ocena stopnia ubytku wierzchniej warstwy, u dołu spodniej

\begin{tabular}{|l|l}
\hline Mikstion 3h Lefranc + farba olejna In- & 4,7
\end{tabular} dian Yellow Van Gogh Talens
Powierzchnia błyszcząca. Przy odrywaniu taśmy odeszła w całości wierzchnia warstwa w jednej z płytek i częściowo w drugiej. U góry ocena stopnia ubytku wierzchniej warstwy, 
Szczególnie duży wpływ warstwy wierzchniej na przyczepność spodniej odnotowano przy zastosowaniu jako warstwy spodniej werniksu Acrylic Varnish Glossy 114 Talens. Badania pojedynczej powłoki werniksu wykazały jego dobra przyczepność do podłoża. Werniks ten, oparty na polimetakrylanie izobutylu, nie rozpuszcza się pod wpływem lakierów w alkoholu etylowym i butylowym oraz 1-metoksy-2-propanolu, a także w acetonie z dodatkiem DPM. Przeprowadzone badania wykazały jednak, że przyczepność lakierów z żywic sztucznych i naturalnych zawierających te rozpuszczalniki do powłoki Acrylic Varnish Glossy 114 Talens była bardzo słaba. Na większości próbek warstwa wierzchnia odchodziła podczas badania razem z taśma.

Podobnie odspajały się warstwy lakieru Bernsteinlack echt Kremer, farby do szkła Decorfin Glass Talens i mikstionu 3h Lefranc. Dobra przyczepność wykazały powłoki Lustrina Restaurarte i farby do szkła Idea Vetro Maimeri, a także lakiery olejno-żywiczne i werniks Dammar Varnish Glossy 081 Talens. Ich dobra przyczepność do warstwy spodniej wiązała się jednak z utratą dobrej adhezji tejże warstwy do podłoża. Najlepszy rezultat dało zastosowanie jako warstwy wierzchniej werniksu Picture Varnish Glossy 002 Talens - ma ona dobra przyczepność do warstwy spodniej i nie wpływa na osłabienie jej przyczepności do podłoża. 


\begin{tabular}{|c|c|c|c|}
\hline \multicolumn{4}{|c|}{$\begin{array}{l}\text { Tabela XIII. Lakiery dwuwarstwowe - badanie przyczepności (po } 4 \text { miesiącach od nałożenia), } \\
\text { temp } 20^{\circ} \mathrm{C} \text {, wilg. } 30 \%\end{array}$} \\
\hline Lakier - warstwa spodnia & Lakier - warstwa wierzchnia & Wynik & Opis \\
\hline \multirow{8}{*}{$\begin{array}{l}\text { Bernsteinlack echt Kremer } \\
+ \text { farba olejna Indian Yel- } \\
\text { low } 244 \text { Van Gogh Talens } \\
\text { Warunki nakładania } \\
\text { Temp 20C, wilg. 50\% } \\
\text { Ocena przyczepności poje- } \\
\text { dynczej warstwy: } 1,0\end{array}$} & $\begin{array}{l}\text { Olej Iniany, mastyks, olejek terpen- } \\
\text { tynowy }(1: 1: 1)+\text { farba olejna Rose } \\
\text { Madder } 329\end{array}$ & 1,0 & $\begin{array}{l}\text { Powierzchnia błyszcząca. Bardzo dobra adhezja } \\
\text { między warstwami (widoczna granica). Ocena stop- } \\
\text { nia ubytku dotyczy obu warstw }\end{array}$ \\
\hline & \begin{tabular}{|l|} 
Kopal z Madagaskaru, olej Iniany, \\
olejek terpentynowy (2:1:2) + farba \\
olejna Indian Yellow 244
\end{tabular} & 0,5 & $\begin{array}{l}\text { Powierzchnia błyszcząca. Bardzo dobra adhezja } \\
\text { między warstwami (widoczna granica). Ocena stop- } \\
\text { nia ubytku dotyczy obu warstw }\end{array}$ \\
\hline & $\begin{array}{l}\text { Acrylic Varnish Glossy } 114 \text { Talens } \\
+ \text { farba olejna Indian Yellow } 244 \\
\text { Van Gogh Talens }\end{array}$ & 0,2 & $\begin{array}{l}\text { Powierzchnia błyszcząca. Bardzo dobry efekt! Bar- } \\
\text { dzo dobra adhezja miedzy warstwami (widoczna } \\
\text { granica). Ocena stopnia ubytku dotyczy obu warstw }\end{array}$ \\
\hline & $\begin{array}{l}\text { Damara Varnish Glossy } 081 \text { Ta- } \\
\text { lens + farba olejna Phthalo Blue } \\
570 \text { Rembrandt Talens }\end{array}$ & 2,8 & $\begin{array}{l}\text { Powierzchnia błyszcząca, po oderwaniu taśmy ma- } \\
\text { towa. Dobra adhezja między warstwami (widoczna } \\
\text { granica). Ocena stopnia ubytku dotyczy obu warstw }\end{array}$ \\
\hline & $\begin{array}{l}\text { Picture Varnish Glossy } 002 \text { Talens } \\
\text { + farba olejna Phthalo Blue Green } \\
576 \text { Rembrandt Talens }\end{array}$ & 0,3 & $\begin{array}{l}\text { Powierzchnia błyszcząca. Bardzo dobra adhezja } \\
\text { miedzy warstwami (widoczna granica). Ocena stop- } \\
\text { nia ubytku dotyczy obu warstw }\end{array}$ \\
\hline & $\begin{array}{l}\text { Decorfin Glass Red } 300 \text { Talens + } \\
\text { white spirit D } 40(2: 1)\end{array}$ & 0,8 & $\begin{array}{l}\text { Powierzchnia błyszcząca. Bardzo dobry efekt. Bar- } \\
\text { dzo dobra adhezja miedzy warstwami (widoczna } \\
\text { granica). Ocena stopnia ubytku dotyczy obu warstw }\end{array}$ \\
\hline & $\begin{array}{l}\text { Damara, olej Iniany, olejek terpen- } \\
\text { tynowy }(2: 3: 3)+\text { farba olejna In- } \\
\text { dian Yellow } 244\end{array}$ & 1,0 & $\begin{array}{l}\text { Powierzchnia błyszcząca. Bardzo dobra adhezja } \\
\text { między warstwami (widoczna granica). Ocena stop- } \\
\text { nia ubytku dotyczy obu warstw }\end{array}$ \\
\hline & $\begin{array}{l}\text { Mikstion 3h Lefranc + farba olej- } \\
\text { na Rose Madder } 329 \text { Rembrandt } \\
\text { Talens }\end{array}$ & 1,0 & $\begin{array}{l}\text { Powierzchnia błyszcząca, po oderwaniu taśmy bez } \\
\text { zmian. Bardzo dobry efekt. Bardzo dobra adhezja } \\
\text { między warstwami (widoczna granica). Ocena stop- } \\
\text { nia ubytku dotyczy obu warstw }\end{array}$ \\
\hline
\end{tabular}

Bardzo dobry rezultat przyniosło zastosowanie jako pierwszej warstwy Bernsteinlack echt Kremer. Zestaw lakierów, które można nanieść na jego powierzchnię, jest ograniczony ze względu na obecność w jego składzie oleju. Zarówno lakiery olejno-żywiczne, jak i gotowe werniksy Acrylic Varnish Glossy 114 Talens i Picture Varnish Glossy 002 Talens wykazały bardzo dobra przyczepność do Bernsteinlack echt i nie wpłynęły na poziom jego przyczepności do podłoża. Obniżył ją jedynie werniks Dammar Varnish Glossy 081 Talens. 


\begin{tabular}{|c|c|c|c|}
\hline \multicolumn{4}{|c|}{$\begin{array}{l}\text { Tabela XIV. Lakiery dwuwarstwowe - badanie przyczepności (po } 4 \text { miesiącach od nałożenia), } \\
\text { temp } 20^{\circ} \mathrm{C} \text {, wilg. } 30 \%\end{array}$} \\
\hline Lakier - warstwa spodnia & Lakier - warstwa wierzchnia & Wynik & Opis \\
\hline \multirow{9}{*}{$\begin{array}{l}\text { Decorfin Glass Yellow } 200 \\
\text { Talens + benzyna lakowa } \\
\text { Warunki nakładania } \\
\text { Temp 20C, wilg. 50\% } \\
\text { Ocena przyczepności poje- } \\
\text { dynczej warstwy: 0,3 }\end{array}$} & $\begin{array}{l}\text { Olej Iniany, mastyks, olejek terpen- } \\
\text { tynowy }(1: 1: 1)+\text { farba olejna Rose } \\
\text { Madder } 329\end{array}$ & 0,3 & $\begin{array}{l}\text { Powierzchnia lekko błyszcząca. Bardzo dobry efekt. } \\
\text { Bardzo dobra adhezja miedzy warstwami (widoczna } \\
\text { granica). Ocena stopnia ubytku dotyczy obu warstw }\end{array}$ \\
\hline & $\begin{array}{l}\text { Kopal z Madagaskaru, olej Iniany, } \\
\text { olejek terpentynowy (2:1:2) + farba } \\
\text { olejna Indian Yellow } 244\end{array}$ & 0,0 & $\begin{array}{l}\text { Powierzchnia błyszcząca. Bardzo dobry efekt. Bar- } \\
\text { dzo dobra adhezja miedzy warstwami (widoczna } \\
\text { granica). Ocena stopnia ubytku dotyczy obu warstw }\end{array}$ \\
\hline & \multirow{2}{*}{$\begin{array}{l}\text { Acrylic Varnish Glossy } 114 \text { Talens } \\
+ \text { farba olejna Indian Yellow } 244 \\
\text { Van Gogh Talens }\end{array}$} & 1,3 & \multirow[t]{2}{*}{$\begin{array}{l}\text { Powierzchnia błyszcząca. U góry ocena stopnia } \\
\text { ubytku wierzchniej warstwy, u spodniej }\end{array}$} \\
\hline & & 0,2 & \\
\hline & $\begin{array}{l}\text { Damara Varnish Glossy } 081 \text { Ta- } \\
\text { lens + farba olejna Phthalo Blue } \\
570 \text { Rembrandt Talens }\end{array}$ & 1,8 & $\begin{array}{l}\text { Powierzchnia błyszcząca, po oderwaniu taśmy lek- } \\
\text { ko matowa. U góry ocena stopnia ubytku wierzch- } \\
\text { niej warstwy, u dołu spodniej }\end{array}$ \\
\hline & \multirow{2}{*}{$\begin{array}{l}\text { Picture Varnish Glossy } 002 \text { Talens } \\
\text { + farba olejna Phthalo Blue Green } \\
576 \text { Rembrandt Talens }\end{array}$} & 1,3 & \multirow{2}{*}{$\begin{array}{l}\text { Powierzchnia błyszcząca, po oderwaniu taśmy lek- } \\
\text { ko matowa. U góry ocena stopnia ubytku wierzch- } \\
\text { niej warstwy, u dołu spodniej }\end{array}$} \\
\hline & & 0,2 & \\
\hline & $\begin{array}{l}\text { Damara, olej Iniany, olejek terpen- } \\
\text { tynowy }(2: 3: 3)+\text { farba olejna In- } \\
\text { dian Yellow } 244\end{array}$ & 0,8 & $\begin{array}{l}\text { Powierzchnia błyszcząca. Bardzo dobra adhezja } \\
\text { między warstwami (widoczna granica). Ocena stop- } \\
\text { nia ubytku dotyczy obu warstw }\end{array}$ \\
\hline & $\begin{array}{l}\text { Mikstion } 3 \mathrm{~h}+\text { farba olejna Rose } \\
\text { Madder } 329 \text { Rembrandt Talens }\end{array}$ & 0,5 & $\begin{array}{l}\text { Powierzchnia błyszcząca. Bardzo dobra adhezja } \\
\text { między warstwami (widoczna granica). Ocena stop- } \\
\text { nia ubytku dotyczy obu warstw }\end{array}$ \\
\hline
\end{tabular}

Dobry wynik uzyskano również, stosując jako pierwszą warstwę farbę do szkła Decorfin Glass Talens. Nakładane jako wierzchnia warstwa lakiery olejno-żywiczne miały bardzo dobra przyczepność do warstwy spodniej i nie spowodowały utraty jej przyczepności do podłoża. Nieco słabszą przyczepność wykazały werniksy Acrylic Varnish Glossy 114 Talens i Picture Varnish Glossy 002 Talens i Dammar Varnish Glossy 081 Talens, ale nie wpływały niekorzystnie na przyczepność warstwy spodniej do podłoża. 


\begin{tabular}{|c|c|c|c|}
\hline \multicolumn{4}{|c|}{$\begin{array}{c}\text { Tabela XV. Lakiery dwuwarstwowe - badanie przyczepności (po } 4 \text { miesiącach od nałożenia), } \\
\text { temp } 20^{\circ} \mathrm{C} \text {, wilg. } 30 \%\end{array}$} \\
\hline Lakier - warstwa spodnia & Lakier - warstwa wierzchnia & W & \begin{tabular}{|c|} 
Opis \\
\end{tabular} \\
\hline \multirow{2}{*}{$\begin{array}{l}\text { Zaponlack Kremer + bar- } \\
\text { wnik Savinyl Gelb RLSN } \\
\text { Clariant }\end{array}$} & \begin{tabular}{|l|}
$20 \%$ Regalrez 1094 w white spirit \\
D40 + farba olejna Indian Yellow
\end{tabular} & 1,9 & $\begin{array}{l}\text { Powierzchnia półmatowa, po oderwaniu taśmy ma- } \\
\text { towa. Ocena stopnia ubytku dotyczy obu warstw }\end{array}$ \\
\hline & $\begin{array}{l}\text { 14\% Paraloid B-44 w [toluenie }+ \\
\text { DPM (2:1)] + barwnik spirytusowy } \\
\text { Blau 807 BASF } \\
\end{array}$ & 1,4 & $\begin{array}{l}\text { Źle się nanosi (rozpuszcza spodnią warstwę) Po- } \\
\text { wierzchnia błyszcząca. Brak widocznego podziału } \\
\text { na } 2 \text { warstwy. Opis dotyczy stopnia ubytku warstwy }\end{array}$ \\
\hline \multirow{2}{*}{$\begin{array}{l}\text { Warunki nakładania } \\
\text { Temp 20C, wilg. } 50 \% \\
\text { Ocena przyczepności poje- } \\
\text { dynczej warstwy: } 0,3\end{array}$} & \multirow{2}{*}{$\begin{array}{l}15 \% \text { Sandarak w alkoholu butylo- } \\
\text { wym + barwnik Savinyl Rot RLSN } \\
\text { Clariant }\end{array}$} & 1,0 & \multirow{2}{*}{$\begin{array}{l}\text { Powierzchnia błyszcząca, po oderwaniu taśmy lekko } \\
\text { zmatowiona. Dobra adhezja między warstwami (wi- } \\
\text { doczna granica). U góry ocena stopnia uszkodzenia } \\
\text { (mikrospękania) wierzchniej warstwy. Spodnia wy- } \\
\text { kazuje bardzo dobrą przyczepność }\end{array}$} \\
\hline & & 0,0 & \\
\hline & \multirow{2}{*}{$\begin{array}{l}\text { Olej Iniany, mastyks, olejek terpen- } \\
\text { tynowy }(1: 1: 1) \text { + farba olejna Ro- } \\
\text { se Madder } 329 \text { Rembrandt Talens }\end{array}$} & 2,9 & \multirow{2}{*}{$\begin{array}{l}\text { Powierzchnia błyszcząca, po oderwaniu taśmy lekkc } \\
\text { zmatowiona. U góry ocena stopnia ubytku wierzch- } \\
\text { niej warstwy. Spodnia wykazuje bardzo dobrą przy- } \\
\text { czepność }\end{array}$} \\
\hline & & 0,0 & \\
\hline & \multirow{2}{*}{\begin{tabular}{|l|} 
Kopal z Madagaskaru, olej Iniany, \\
olejek terpentynowy (2:1:2) + farba \\
olejna Indian Yellow 244
\end{tabular}} & 3,4 & \multirow{2}{*}{$\begin{array}{l}\text { Powierzchnia błyszcząca. U góry ocena stopnia } \\
\text { ubytku wierzchniej warstwy. Spodnia wykazuje bar- } \\
\text { dzo dobrą przyczepność }\end{array}$} \\
\hline & & 0,0 & \\
\hline & \multirow{2}{*}{$\begin{array}{l}\text { Acrylic Varnish Glossy } 114 \text { Talens } \\
+ \text { farba olejna Indian Yellow } 244 \\
\text { Van Gogh Talens }\end{array}$} & 1,3 & \multirow{2}{*}{$\begin{array}{l}\text { Powierzchnia lekko błyszcząca. U góry ocena stop- } \\
\text { nia ubytku wierzchniej warstwy. Spodnia wykazuje } \\
\text { bardzo dobrą przyczepność }\end{array}$} \\
\hline & & 0,0 & \\
\hline & \multirow{2}{*}{$\begin{array}{l}\text { Damara Varnish Glossy } 081 \text { Ta- } \\
\text { lens + farba olejna Phthalo Blue } \\
570 \text { Rembrandt Talens }\end{array}$} & 2,0 & \multirow{2}{*}{$\begin{array}{l}\text { Powierzchnia błyszcząca, po oderwaniu taśmy lekko } \\
\text { zmatowiona. U góry ocena stopnia ubytku wierzch- } \\
\text { niej warstwy. Spodnia wykazuje bardzo dobrą przy- } \\
\text { czepność }\end{array}$} \\
\hline & & 0,0 & \\
\hline & \multirow{2}{*}{$\begin{array}{l}\text { Picture Varnish Glossy } 002 \text { Talens } \\
\text { + farba olejna Phthalo Blue Green } \\
576 \text { Rembrandt Talens }\end{array}$} & 2,0 & \multirow{2}{*}{$\begin{array}{l}\text { Powierzchnia błyszcząca, po oderwaniu taśmy de- } \\
\text { likatnie matowa. U góry ocena stopnia ubytkL } \\
\text { wierzchniej warstwy. Spodnia wykazuje bardzo do- } \\
\text { brą przyczepność! }\end{array}$} \\
\hline & & 0,0 & \\
\hline & $\begin{array}{l}\text { Bernsteinlack echt Kremer + far- } \\
\text { ba olejna Indian Yellow } 244 \text { Van } \\
\text { Gogh Talens }\end{array}$ & 0,3 & $\begin{array}{l}\text { Powierzchnia błyszcząca. Bardzo dobra adhezja } \\
\text { między warstwami. Ocena stopnia ubytku dotyczy } \\
\text { obu warstw. Dobry efekt }\end{array}$ \\
\hline & \multirow{2}{*}{$\begin{array}{l}\text { Decorfin Glass Blue } 500+501 \\
\text { Talens + white spirit D } 40\end{array}$} & 3,4 & \multirow{2}{*}{$\begin{array}{l}\text { Powierzchnia błyszcząca. W jednej z płytek przy od- } \\
\text { rywaniu taśmy cześć wierzchniej warstwy odeszła } \\
\text { z nią. U góry ocena stopnia ubytku wierzchniej war- } \\
\text { stwy. Spodnia wykazuje bardzo dobrą przyczepność }\end{array}$} \\
\hline & & 0,0 & \\
\hline & $\begin{array}{l}\text { Damara, olej Iniany, olejek terpen- } \\
\text { tynowy (2:3:3) + farba olejna In- } \\
\text { dian Yellow } 244\end{array}$ & 0,7 & $\begin{array}{l}\text { Powierzchnia błyszcząca. Bardzo dobra przyczep- } \\
\text { ność między warstwami. Ocena stopnia ubytku do- } \\
\text { tyczy obu warstw. Dobry efekt }\end{array}$ \\
\hline
\end{tabular}


Szczególnie istotne były wyniki zastosowania jako warstwy spodniej lakieru Zaponlack Kremer, często używanego przez pozłotników do zabezpieczania pozłoty. Zaponlack jako warstwa samodzielna otrzymał bardzo dobrą ocenę przyczepności, wynosiła ona 0,3. Przeprowadzone doświadczenia wykazały, że nakładanie kolejnych warstw nie wpływa na zmianę jego przyczepności do podłoża. Bardzo dobry rezultat dało pokrycie go warstwą Bernsteinlack echt Kremer. Dobry efekt uzyskano z lakierem sandarakowym w alkoholu butylowym, ale należy pamiętać, że nakładany zbyt długo może rozpuszczać warstwę spodnią. Zbliżona, średnia przyczepność do powłoki Zaponlacku wykazuja werniksy Acrylic Varnish Glossy 114 Talens, Picture Varnish Glossy 002 Talens i Dammar Varnish Glossy 081 Talens, natomiast słabą lakiery olejno-żywiczne i farby do szkła Decorfin Glass Talens. Wyjątek stanowi lakier olejno-żywiczny o składzie: damara, olej lniany, olejek terpentynowy, którego przyczepność jest bardzo dobra. 


\begin{tabular}{|c|c|c|c|}
\hline \multicolumn{4}{|c|}{$\begin{array}{l}\text { Tabela XVI. Lakiery dwuwarstwowe - badanie przyczepności (po } 4 \text { miesiącach od nałożenia), } \\
\text { temp 20ㄷ, wilg. } 30 \%\end{array}$} \\
\hline Lakier - warstwa spodnia & Lakier - warstwa wierzchnia & Wynik & Opis \\
\hline \multirow{22}{*}{$\begin{array}{l}\text { Incral } 44+\text { barwnik Savinyl } \\
\text { Gelb RLSN Clariant } \\
\text { Warunki nakładania } \\
\text { Temp 20C, wilg. } 50 \% \\
\text { Ocena przyczepności poje- } \\
\text { dynczej warstwy: } 2,6\end{array}$} & $\begin{array}{l}\text { 20\% Paraloid B-72 w 1-metok- } \\
\text { sy-2-propanolu + barwnik Savinyl } \\
\text { Rot RLSN Clariant }\end{array}$ & 2,5 & $\begin{array}{l}\text { Powierzchnia błyszcząca. Bardzo dobra adhezja } \\
\text { między warstwami (brak wyraźnej granicy). Oce- } \\
\text { na stopnia uszkodzenia ubytku dotyczy obu warstw }\end{array}$ \\
\hline & \multirow{2}{*}{$\begin{array}{l}\text { 20\% Regalrez } 1094 \text { w white spirit } \\
\text { D40 + farba olejna Indian Yellow }\end{array}$} & 0,9 & \multirow{2}{*}{$\begin{array}{l}\text { Powierzchnia półmatowa, po oderwaniu taśmy ma- } \\
\text { towa. Naruszona powierzchnia wierzchniej warstwy. } \\
\text { U góry ocena stopnia ubytku wierzchniej warstwy. } \\
\text { Spodnia wykazuje bardzo dobrą przyczepność }\end{array}$} \\
\hline & & 0,1 & \\
\hline & $\begin{array}{l}\text { 11\% Paraloid B-72 w [alkoholu } \\
\text { etylowym + DPM (1:1)] + barwnik } \\
\text { Blau } 807 \text { BASF }\end{array}$ & 1,3 & $\begin{array}{l}\text { Ładny efekt. Powierzchnia błyszcząca. Bardzo dobra } \\
\text { adhezja między warstwami (brak wyraźnej granicy).. } \\
\text { Ocena stopnia ubytku dotyczy obu warstw }\end{array}$ \\
\hline & $\begin{array}{l}15 \% \text { Szelak bielony w alkoholu } \\
\text { etylowym + barwnik Savinyl Rot } \\
\text { RLSN Clariant }\end{array}$ & 1,8 & $\begin{array}{l}\text { Powierzchnia błyszcząca. Bardzo dobra adhezja } \\
\text { między warstwami (brak wyraźnej granicy). Ocena } \\
\text { stopnia ubytku dotyczy obu warstw }\end{array}$ \\
\hline & $\begin{array}{l}\text { 15\% Sandarak w alkoholu butylo- } \\
\text { wym + barwnik Savinyl Rot RLSN } \\
\text { Clariant }\end{array}$ & 2,0 & $\begin{array}{l}\text { Powierzchnia błyszcząca, po oderwaniu taśmy de- } \\
\text { likatnie zmatowiona. Bardzo dobra adhezja między } \\
\text { warstwami (brak wyraźnej granicy). Ocena stopnia } \\
\text { ubytku dotyczy obu warstw }\end{array}$ \\
\hline & $\begin{array}{l}\text { 14\% Szelak złocisty (nieodwosk.) } \\
\text { w [alkoholu etylowym + DPM } \\
(2: 1) \text { ] barwnik Blau } 807 \text { BASF }\end{array}$ & 0,8 & $\begin{array}{l}\text { Powierzchnia lekko błyszcząca. Bardzo dobra adhe- } \\
\text { zja między warstwami (brak wyraźnej granicy). Oce- } \\
\text { na stopnia ubytku dotyczy obu warstw. Dobry efekt }\end{array}$ \\
\hline & \multirow{2}{*}{$\begin{array}{l}\text { Olej Iniany, mastyks, olejek terpen- } \\
\text { tynowy }(1: 1: 1)+\text { farba olejna Ro- } \\
\text { se Madder } 329 \text { Rembrandt Talens }\end{array}$} & 3,2 & \multirow{2}{*}{$\begin{array}{l}\text { Powierzchnia błyszcząca, po oderwaniu taśmy de- } \\
\text { likatnie zmatowiona. U góry ocena stopnia ubytku } \\
\text { wierzchniej warstwy, u dołu spodniej }\end{array}$} \\
\hline & & 2,0 & \\
\hline & \multirow{2}{*}{$\begin{array}{l}\text { Kopal z Madagaskaru, olej Iniany, } \\
\text { olejek terpentynowy (2:1:2) + farba } \\
\text { olejna Indian Yellow } 244\end{array}$} & 2,4 & \multirow[t]{2}{*}{$\begin{array}{l}\text { Powierzchnia błyszcząca. U góry ocena stopnia } \\
\text { ubytku wierzchniej warstwy, u dołu spodniej }\end{array}$} \\
\hline & & 0,7 & \\
\hline & \multirow{2}{*}{$\begin{array}{l}\text { Acrylic Varnish Glossy } 114 \text { Talens } \\
+ \text { farba olejna Indian Yellow } 244 \\
\text { Van Gogh Talens }\end{array}$} & 1,7 & \multirow{2}{*}{$\begin{array}{l}\text { Powierzchnia lekko błyszcząca. U góry ocena stop- } \\
\text { nia ubytku wierzchniej warstwy, u dołu spodniej }\end{array}$} \\
\hline & & 0,6 & \\
\hline & \multirow{2}{*}{\begin{tabular}{|l|} 
Damara Varnish Glossy 081 Ta- \\
lens + farba olejna Phthalo Blue \\
570 Rembrandt Talens
\end{tabular}} & 2,6 & \multirow{2}{*}{$\begin{array}{l}\text { Powierzchnia błyszcząca, po oderwaniu taśmy zma- } \\
\text { towiona. U góry ocena stopnia ubytku wierzchniej } \\
\text { warstwy, u dołu spodniej }\end{array}$} \\
\hline & & 1,2 & \\
\hline & \multirow{2}{*}{$\begin{array}{l}\begin{array}{l}\text { Picture Varnish Glossy } 002 \text { Talens } \\
\text { + farba olejna Phthalo Blue Green } \\
576 \text { Rembrandt Talens }\end{array} \\
\end{array}$} & 1,3 & \multirow{2}{*}{$\begin{array}{l}\text { Powierzchnia błyszcząca, po oderwaniu taśmy } \\
\text { zmatowiona. Opis u góry dotyczy stopnia ubytku } \\
\text { wierzchniej warstwy, a u dołu ubytku spodniej }\end{array}$} \\
\hline & & 0,5 & \\
\hline & $\begin{array}{l}\text { Decorfin Glass Blue } 500+501 \\
\text { Talens + white spirit D40 }(2: 1)\end{array}$ & 0,9 & $\begin{array}{l}\text { Powierzchnia błyszcząca. Bardzo dobra adhezja } \\
\text { między warstwami (widoczna granica). Ocena stop- } \\
\text { nia ubytku dotyczy obu warstw. Dobry efekt }\end{array}$ \\
\hline & $\begin{array}{l}\text { Zaponlack Kremer + barwnik Savi- } \\
\text { nyl Rot RLSN Clariant }\end{array}$ & 0,0 & $\begin{array}{l}\text { Powierzchnia błyszcząca. Bardzo dobra adhezja } \\
\text { między warstwami (brak wyraźnej granicy). Ocena } \\
\text { stopnia ubytku dotyczy obu warstw. Dobry efekt! }\end{array}$ \\
\hline & Lakier szelakowy blue + DPM (2:1) & 1,0 & $\begin{array}{l}\text { Nieładny efekt, zaplamienia. Wierzchnia warstwa } \\
\text { rozpuszcza spodnią. Powierzchnia o lekkim poły- } \\
\text { sku. Bardzo dobra adhezja między warstwami (brak } \\
\text { wyraźnej granicy). Ocena stopnia ubytku dotyczy } \\
\text { obu warstw }\end{array}$ \\
\hline & $\begin{array}{l}\text { Idea Vetro } 202 \text { Rose Maimeri }+ \\
\text { DPM (2:1) }\end{array}$ & 2,6 & $\begin{array}{l}\text { Powierzchnia błyszcząca. Bardzo dobra adhezja } \\
\text { między warstwami (widoczna granica). Ocena stop- } \\
\text { nia ubytku dotyczy obu warstw }\end{array}$ \\
\hline & $\begin{array}{l}\text { 20\% Szelak bielony w 1-metoksy- } \\
\text {-2-propanolu + barwnik Blau } 807 \\
\text { BASF }\end{array}$ & 1,2 & $\begin{array}{l}\text { Powierzchnia błyszcząca. Bardzo dobra adhezja } \\
\text { między warstwami (brak wyraźnej granicy). Ocena } \\
\text { stopnia ubytku dotyczy obu warstww }\end{array}$ \\
\hline
\end{tabular}


Równie często jak Zaponlack, stosowany w pozłotnictwie i do zabezpieczania metalowych przedmiotów jest lakier o nazwie Incral 44 CTS. Badania przyczepności pojedynczej warstwy Incralu 44 CTS wykazały niezbyt dobra przyczepność do podłoża. Natomiast w układach dwuwarstwowych uzyskano zdecydowanie lepsze rezultaty, porównywalne z przyczepnością Incralu 44 CTS modyfikowanego dodatkiem DPM w układach jednowarstwowych (ocena 0,8-1,3). Bardzo dobre efekty otrzymano po naniesieniu jako warstwy wierzchniej Zapolacku, poprawiła się przyczepność obu warstw do podłoża. Naniesienie jako drugiej warstwy lakierów szelakowych również nie wywarło negatywnego wpływu na przyczepność spodniej warstwy do podłoża. Należy jednak pamiętać, że podczas długotrwałego nakładania moga one rozpuszczać Incral 44 CTS. Na pewno nie rozpuszczaja go i nie powoduja utraty przyczepności werniksy Acrylic Varnish Glossy 114 Talens, Picture Varnish Glossy 002 Talens, Dammar Varnish Glossy 081 Talens i Regalrez 1094 w white spirit D40, a także farby do szkła Decorfin Glass Talens. 


\begin{tabular}{|c|c|c|c|}
\hline \multicolumn{4}{|c|}{$\begin{array}{l}\text { Tabela XVII. Lakiery dwuwarstwowe - badanie przyczepności (po } 4 \text { miesiącach od nałożenia), } \\
\text { temp } 20^{\circ} \text { C, wilg. } 30 \%\end{array}$} \\
\hline Lakier - warstwa spodnia & Lakier - warstwa wierzchnia & Wynik & Opis \\
\hline \multirow{14}{*}{$\begin{array}{l}\text { Lakier szelakowy citron + } \\
\text { DPM (2:1) } \\
\text { Warunki nakładania } \\
\text { Temp 20C, wilg. 50\% } \\
\text { Ocena przyczepności poje- } \\
\text { dynczej warstwy: 0,8 }\end{array}$} & \begin{tabular}{|l|}
$20 \%$ Regalrez 1094 w white spirit \\
D40 + farba olejna Indian Yellow \\
Van Gogh Talens
\end{tabular} & 0,1 & $\begin{array}{l}\text { Powierzchnia półmatowa, po oderwaniu taśmy ma- } \\
\text { towa. Drobiny wierzchniej warstwy pozostają na } \\
\text { taśmie. Bardzo dobra adhezja między warstwami } \\
\text { (widoczna granica). Ocena stopnia ubytku doty- } \\
\text { czy obu warstw }\end{array}$ \\
\hline & $\begin{array}{l}\text { 14\% Paraloid B-44 w [toluenie + } \\
\text { DPM (2:1)] + barwnik spirytusowy } \\
\text { Blau 807 BASF }\end{array}$ & 2,5 & $\begin{array}{l}\text { Powierzchnia błyszcząca. Bardzo dobra adhezja } \\
\text { między warstwami (brak wyraźnej granicy). Ocena } \\
\text { stopnia ubytku dotyczy obu warstw }\end{array}$ \\
\hline & $\begin{array}{l}15 \% \text { Szelak złocisty (nieodwosk.) } \\
\text { w alkoholu butylowym + barwnik } \\
\text { Blau } 807 \text { BASF }\end{array}$ & 0,5 & $\begin{array}{l}\text { Powierzchnia błyszcząca. Bardzo dobra adhezja } \\
\text { między warstwami (brak wyraźnej granicy). Oce- } \\
\text { na stopnia uszkodzenia (mikrospękania) dotyczy } \\
\text { obu warstw }\end{array}$ \\
\hline & \begin{tabular}{|l|} 
Olej Iniany, mastyks, olejek terpen- \\
tynowy $(1: 1: 1)+$ farba olejna Rose \\
Madder 329 \\
\end{tabular} & 0,5 & $\begin{array}{l}\text { Powierzchnia błyszcząca. Bardzo dobra adhezja } \\
\text { między warstwami (widoczny podział). Ocena stop- } \\
\text { nia ubytku dotyczy obu warstw. Bardzo ładny efekt }\end{array}$ \\
\hline & $\begin{array}{l}\text { Kopal z Madagaskaru, olej Iniany, } \\
\text { olejek terpentynowy }(2: 1: 2)+\text { farba } \\
\text { olejna Indian Yellow } 244\end{array}$ & 0,2 & $\begin{array}{l}\text { Powierzchnia błyszczaca. Bardzo dobra adhezja } \\
\text { między warstwami (widoczna granica). Ocena stop- } \\
\text { nia ubytku dotyczy obu warstw. Bardzo tadny efekt }\end{array}$ \\
\hline & $\begin{array}{l}\text { Acrylic Varnish Glossy } 114 \text { Talens } \\
+ \text { farba olejna Indian Yellow } 244 \\
\text { Van Gogh Talens } \\
\end{array}$ & 0,8 & $\begin{array}{l}\text { Powierzchnia błyszcząca. Bardzo dobra adhezja } \\
\text { między warstwami (widoczna granica). Ocena stop- } \\
\text { nia ubytku dotyczy obu warstw. Dobry efekt } \\
\end{array}$ \\
\hline & \multirow{2}{*}{$\begin{array}{l}\text { Damara Varnish Glossy } 081 \text { Ta- } \\
\text { lens + farba olejna Phthalo Blue } \\
570 \text { Rembrandt Talens }\end{array}$} & 2,3 & \multirow{2}{*}{$\begin{array}{l}\text { Powierzchnia błyszcząca, po oderwaniu taśmy zma- } \\
\text { towiała. Drobiny wierzchniej warstwy pozostają na } \\
\text { taśmie. U góry ocena stopnia ubytku wierzchniej } \\
\text { warstwy, u dołu spodniej }\end{array}$} \\
\hline & & 0,3 & \\
\hline & \begin{tabular}{|l|} 
Bernsteinlack echt Kremer + far- \\
ba olejna Rose Madder 329 Rem- \\
brandt Talens
\end{tabular} & 0,3 & $\begin{array}{l}\text { Powierzchnia błyszcząca. Bardzo dobra adhezja } \\
\text { między warstwami (widoczna granica). Ocena stop- } \\
\text { nia ubytku dotyczy obu warstw. Bardzo tadny efekt }\end{array}$ \\
\hline & \begin{tabular}{l|} 
Decorfin Glass Red 300 Talens + \\
white spirit D 40 (7:3)
\end{tabular} & 0,3 & $\begin{array}{l}\text { Powierzchnia błyszcząca. Bardzo dobra przyczep- } \\
\text { ność między warstwami (widoczna granica). Oce- } \\
\text { na stopnia ubytku dotyczy obu warstw. Bardzo } \\
\text { tadny efekt }\end{array}$ \\
\hline & Lakier szelakowy blue + DPM (2:1) & 0,3 & $\begin{array}{l}\text { Rozpuszcza spodnią warstwę. Brzydki efekt. Po- } \\
\text { wierzchnia błyszcząca. Bardzo dobra adhezja między } \\
\text { warstwami (brak wyraźnej granicy). Ocena stopnia } \\
\text { ubytku dotyczy obu warstw }\end{array}$ \\
\hline & \multirow[t]{2}{*}{ Incral 44+ barwnik Blau 807 BASF } & 2 & \multirow{2}{*}{$\begin{array}{l}\text { Powierzchnia błyszcząca. U góry ocena stopnia } \\
\text { ubytku wierzchniej warstwy, a u dołu spodniej. } \\
\text { Spodnia warstwa wykazuje bardzo dobrą przyczep- } \\
\text { ność }\end{array}$} \\
\hline & & 0,4 & \\
\hline & $\begin{array}{l}\text { Damara, olej Iniany, olejek terpen- } \\
\text { tynowy (2:3:3) + farba olejna In- } \\
\text { dian Yellow } 244\end{array}$ & 0,7 & $\begin{array}{l}\text { Powierzchnia błyszcząca. Ocena dotyczy stopnia } \\
\text { ubytku obu warstw }\end{array}$ \\
\hline
\end{tabular}


Podobnie jak Incral 44 CTS, stosunkowo nie najlepsza przyczepność w pojedynczej warstwie cechowała gotowy lakier szelakowy Edan, natomiast zdecydowanie się poprawiła po zmodyfikowaniu go dodatkiem DPM. Ten właśnie produkt zastosowano jako pierwszą warstwę do badania przyczepności układów dwuwarstwowych. Praktycznie wszystkie naniesione na nią lakiery wykazywały dobra przyczepność i nie wpływały negatywnie na jej adhezję do powierzchni metalowej płytki. Bardzo dobry wynik przyniosło wykorzystanie w drugiej warstwie lakierów olejno-żywicznych: kopalowego, mastyksowego, damarowego, Brensteinlack echt, farb do szkła Decorfin Glass Talens, werniksu Acrylic Varnish Glossy 114 Talens i lakieru Regalrez 1094 w white spirit D40.

Niekorzystny wpływ na przyczepność miał nałożony Paraloid B-44 w toluenie z dodatkiem DPM (2:1). 


\begin{tabular}{|c|c|c|c|}
\hline \multicolumn{4}{|c|}{$\begin{array}{l}\text { Tabela XVIII. Lakiery dwuwarstwowe - badanie przyczepności (po } 4 \text { miesiącach od nałożenia), } \\
\text { temp } 20^{\circ} \mathrm{C} \text {, wilg. } 30 \%\end{array}$} \\
\hline Lakier - warstwa spodnia & Lakier - warstwa wierzchnia & Wynik & \begin{tabular}{|c|} 
Opis \\
\end{tabular} \\
\hline \multirow{10}{*}{$\begin{array}{l}\text { Lustrina Restaurarte + DPM } \\
(2: 1)+\text { barwnik Savinyl } \\
\text { Gelb RSLN Clariant }\end{array}$} & 20\% Regalrez 1094 w white spirit & 2,2 & \multirow{2}{*}{$\begin{array}{l}\text { Powierzchnia lekko błyszcząca, po oderwaniu taśm } \\
\text { matowa. Drobiny wierzchniej warstwy pozostają n } \\
\text { taśmie. U góry ocena stopnia ubytku wierzchnie } \\
\text { warstwy, u dołu spodniej }\end{array}$} \\
\hline & $\begin{array}{l}\text { D40 + tarba olejna Indian Yellow } \\
244 \text { Van Gogh Talens }\end{array}$ & 1,0 & \\
\hline & $\begin{array}{l}\text { Lakier mastyksowo-olejny (sykaty- } \\
\text { wowany) w olejku terpentynowym } \\
\text { + farba olejna Rose Madder } 329\end{array}$ & 3,7 & $\begin{array}{l}\text { Powierzchnia błyszcząca, po oderwaniu taśmy bez } \\
\text { zmian. Bardzo dobra adhezja między warstwami } \\
\text { (widoczna granica). Ocena stopnia ubytku doty- } \\
\text { czy obu warstw }\end{array}$ \\
\hline & $\begin{array}{l}\text { Olej Iniany, mastyks, olejek terpen- } \\
\text { tynowy }(1: 1: 1)+\text { farba olejna In- } \\
\text { dian Yellow } 244 \text { Van Gogh Talens }\end{array}$ & 3,3 & $\begin{array}{l}\text { Powierzchnia błyszcząca. Dobra adhezja między } \\
\text { warstwami (widoczna granica). Ocena stopnia ubyt- } \\
\text { ku dotyczy obu warstw }\end{array}$ \\
\hline & $\begin{array}{l}\text { Damara Varnish Glossy } 081 \text { Ta- } \\
\text { lens + farba olejna Phthalo Blue } \\
570 \text { Rembrandt Talens }\end{array}$ & 2,8 & $\begin{array}{l}\text { Powierzchnia błyszcząca, po oderwaniu taśmy de- } \\
\text { likatne zmatowienie. Dobra adhezja między war- } \\
\text { stwami (widoczna granica). Ocena stopnia ubytku } \\
\text { dotyczy obu warstw }\end{array}$ \\
\hline & $\begin{array}{l}\text { Picture Varnish Glossy } 002 \text { Talens } \\
\text { + farba olejna Phthalo Blue Green } \\
576 \text { Rembrandt Talens }\end{array}$ & 2,3 & $\begin{array}{l}\text { Powierzchnia błyszcząca, po oderwaniu taśmy de- } \\
\text { likatne zmatowienie. Dobra adhezja między war- } \\
\text { stwami (widoczna granica). Ocena stopnia ubytku } \\
\text { dotyczy obu warstw }\end{array}$ \\
\hline & $\begin{array}{l}\text { Bernsteinlack echt Kremer }+ \text { far- } \\
\text { ba olejna Rose Madder Rembrandt } \\
\text { Talens }\end{array}$ & 2,0 & $\begin{array}{l}\text { Powierzchnia błyszcząca. Dobra adhezja między } \\
\text { warstwami (widoczna granica). Ocena stopnia ubyt- } \\
\text { ku dotyczy obu warstw }\end{array}$ \\
\hline & $\begin{array}{l}\text { Decorfin Glass Red } 300 \text { Talens + } \\
\text { white spirit D } 40(2: 1)\end{array}$ & 2,8 & $\begin{array}{l}\text { Powierzchnia błyszcząca. Dobra adhezja między } \\
\text { warstwami (widoczna granica). Ocena stopnia ubyt- } \\
\text { ku dotyczy obu warstw }\end{array}$ \\
\hline & $\begin{array}{l}\text { Damara, olej Iniany, olejek terpen- } \\
\text { tynowy (2:3:3) + farba olejna In- } \\
\text { dian Yellow } 244\end{array}$ & 3,8 & $\begin{array}{l}\text { Powierzchnia błyszcząca. Dobra adhezja między } \\
\text { warstwami (widoczna granica). Ocena stopnia ubyt- } \\
\text { ku dotyczy obu warstw }\end{array}$ \\
\hline & $\begin{array}{l}\text { Mikstion 3h Lefranc + farba olej- } \\
\text { na Rose Madder } 329 \text { Rembrandt } \\
\text { Talens }\end{array}$ & 3,2 & $\begin{array}{l}\text { Powierzchnia błyszcząca. Dobra adhezja między } \\
\text { warstwami (widoczna granica). Ocena stopnia ubyt- } \\
\text { ku dotyczy obu warstw }\end{array}$ \\
\hline
\end{tabular}

Lakier Lustrina Restaurarte nie nadaje się do stosowania jako warstwa spodnia, ponieważ powłoka wykazuje stosunkowo słabą przyczepność w układzie jednowarstwowym. Zdecydowanie lepszą przyczepność wykazuje modyfikowany dodatkiem DPM. W układach dwuwarstwowych jedynie stosunkowo dobry wynik uzyskano po zastosowaniu jej jako spodniej warstwy pod lakier Regalrez 1094 w white spirit D40. 


\begin{tabular}{|c|c|c|c|}
\hline \multicolumn{4}{|c|}{$\begin{array}{l}\text { Tabela XIX. Lakiery dwuwarstwowe - badanie przyczepności (po } 4 \text { miesiącach od nałożenia), } \\
\text { temp } 20^{\circ} \mathrm{C} \text {, wilg. } 30 \%\end{array}$} \\
\hline Lakier - warstwa spodnia & Lakier - warstwa wierzchnia & Wynik & Opis \\
\hline \multirow{8}{*}{$\begin{array}{l}\text { Idea Vetro } 070 \text { Yellow } \\
\text { Maimeri + DPM (2:1) } \\
\text { Warunki nakładania } \\
\text { Temp 20C, wilg. } 50 \% \\
\text { Ocena przyczepności poje- } \\
\text { dynczej warstwy: } 2,1\end{array}$} & $\begin{array}{l}\text { Olej Iniany, mastyks, olejek terpen- } \\
\text { tynowy }(1: 1: 1)+\text { farba olejna Rose } \\
\text { Madder } 329\end{array}$ & 3,5 & $\begin{array}{l}\text { Warstwa błyszcząca. Bardzo dobra adhezja mię- } \\
\text { dzy warstwami (widoczna granica). Ocena stopnia } \\
\text { uszkodzenia dotyczy obu }\end{array}$ \\
\hline & $\begin{array}{l}\text { Kopal z Madagaskaru, olej Iniany, } \\
\text { olejek terpentynowy (2:1:2) + farba } \\
\text { olejna Indian Yellow } 244\end{array}$ & 2,6 & $\begin{array}{l}\text { Warstwa błyszcząca. Bardzo dobra adhezja między } \\
\text { warstwami (widoczna granica). Opis dotyczy stop- } \\
\text { nia ubytku obu warstw }\end{array}$ \\
\hline & $\begin{array}{l}\text { Acrylic Varnish Glossy } 114 \text { Talens } \\
+ \text { farba olejna Indian Yellow } 244\end{array}$ & 1,8 & $\begin{array}{l}\text { Warstwa błyszcząca. Ocena stopnia uszkodzenia do- } \\
\text { tyczy obu warstw }\end{array}$ \\
\hline & \multirow{2}{*}{$\begin{array}{l}\text { Damara Varnish Glossy } 081 \text { Ta- } \\
\text { lens + farba olejna Phthalo Blue } \\
570 \text { Rembrandt Talens }\end{array}$} & 2,6 & \multirow{2}{*}{$\begin{array}{l}\text { Warstwa błyszcząca. Po oderwaniu taśmy warstwa } \\
\text { zmatowiona. U góry ocena stopnia ubytku wierzch- } \\
\text { niej warstwy, u dołu uszkodzenia spodniej }\end{array}$} \\
\hline & & 1,1 & \\
\hline & $\begin{array}{l}\text { Decorfin Glass Red } 300 \text { Talens + } \\
\text { white spirit D40 (2:1) }\end{array}$ & 3,0 & $\begin{array}{l}\text { Warstwa błyszcząca. Dobra adhezja między war- } \\
\text { stwami (widoczna granica między warstwami). Oce- } \\
\text { na stopnia ubytku dotyczy obu warstw }\end{array}$ \\
\hline & $\begin{array}{l}\text { Damara, olej Iniany, olejek terpen- } \\
\text { tynowy }(2: 3: 3)+\text { farba olejna In- } \\
\text { dian Yellow } 244\end{array}$ & 3,1 & $\begin{array}{l}\text { Warstwa błyszcząca. Bardzo dobra adhezja między } \\
\text { warstwami (widoczna granica). Ocena dotyczy stop- } \\
\text { nia ubytku obu warstw }\end{array}$ \\
\hline & $\begin{array}{l}\text { Mikstion 3h Lefranc + farba olej- } \\
\text { na Rose Madder } 329 \text { Rembrandt } \\
\text { Talens }\end{array}$ & 2,8 & $\begin{array}{l}\text { Warstwa błyszcząca. Bardzo dobra adhezja między } \\
\text { warstwami (widoczna granica). Ocena stopnia ubyt- } \\
\text { ku dotyczy obu warstw }\end{array}$ \\
\hline
\end{tabular}

Warstwy lakierów nakładane na powierzchnię farby do szkła Idea Vetro Maimeri z dodatkiem DPM (2:1) nie wpływały w znaczący sposób na osłabienie jej przyczepności do podłoża.

Podsumowując, należy stwierdzić, że przeprowadzone badania wykazały występowanie istotnych zależności między warstwą spodnią a wierzchnią. Można wskazać układy lakierów, gdzie spodnie warstwy wykazują bardzo dobrą przyczepność do podłoża, a nakładane wierzchnie jej nie osłabiaja, same dobrze przylegając do warstwy spodniej. Ze względu na bardzo dobra przyczepność do powierzchni metalicznych godne, polecenia jako warstwy spodnie są lakiery z żywic sztucznych Paraloid B-48N, z naturalnych szelakowe, natomiast z gotowych produktów - Zaponlack Kremer i farby do szkła Decorfin Glass Talens. Zapewniają one również w większości przypadków możliwość nanoszenia na ich powierzchnie innych lakierów, bez utraty ich przyczepności do podłoża. 


\section{Summary}

\section{Research on the adhesion of lacquers in two-layer systems}

In conservation-restoration practice one face the necessity of applying varnishes of lacquers in multiple layers. Beside the lower layer being insoluble by the upper one, important is also their mutual adhesion as well as the influence of the upper layer on the adhesion of lower on to the support. Weak adhesion of lower layer as a rule eliminates the possibility of applying subsequent layers, however tests revealed, that there are exceptions.

The paper presents results of testing the adhesion of lacquers in two-layer set-ups. The research involved broad range of both self-prepared and commercially made lacquers. As lower layers lacquers, that have very good adhesion to the support and are frequently used in practice were applied; as upper layers - lacquers not dissolving the lower ones. The tests were performed following the description comprised in the norm PN-EN ISO 2409.

In the performed tests, apart from assessment of the layers' adhesion, the border between the two coats was analysed - its lack may indicate, that the upper layer affected the lower one. To facilitate assessment of adhesion between the layers, the lacquers were tinted with dyes and oil paints. The obtained results have been presented in tables with a description and short comments placed below tables 


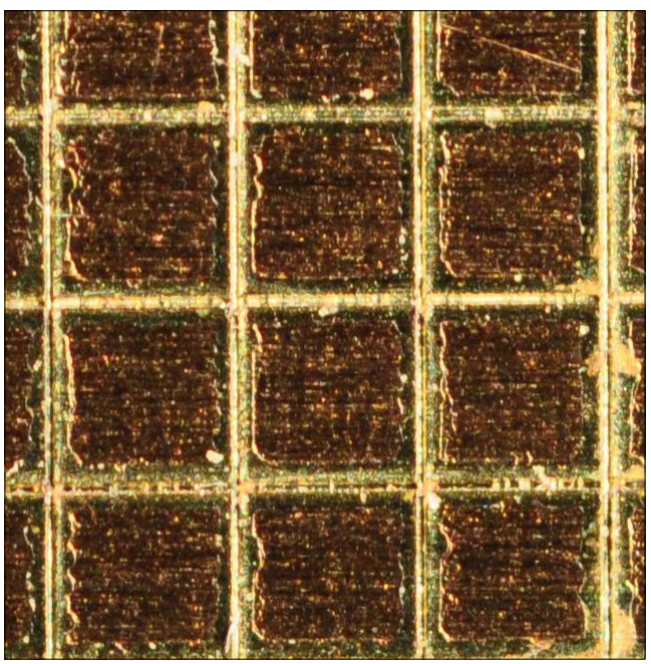

Fot. 1. Spodnia warstwa: 20\% Paraloid B-44 w 1-metoksy-2-propanolu + barwnik Blau 807 BASF. Wierzchnia warstwa: 20\% Szelak bielony w alkoholu etylowym + barwnik Savinyl Rot RLSN Clariant

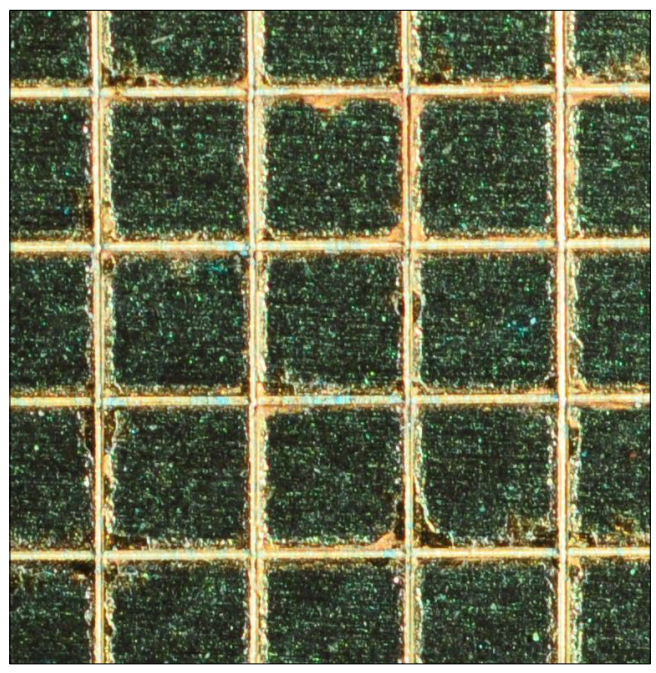

Fot. 2. Spodnia warstwa: 20\% Paraloid B-44 w 1-metoksy-2-propanolu + barwnik Blau 807 BASF. Wierzchnia warstwa: Damara Varnish Glossy 081 


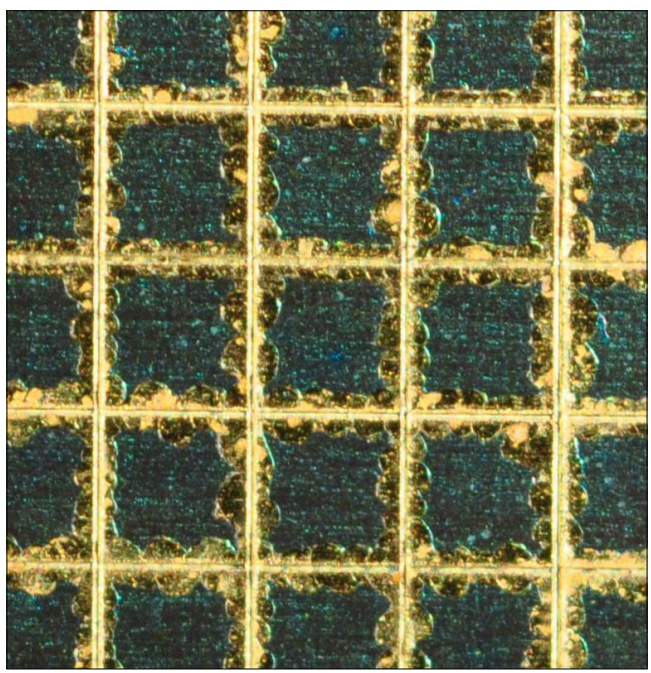

Fot. 3. Spodnia warstwa: $15 \%$ Sandarak w alkoholu butylowym + barwnik Savinyl Gelb RLSN Clariant. Wierzchnia warstwa: Decorfin Glass Blue 500 Talens + white spirit D40

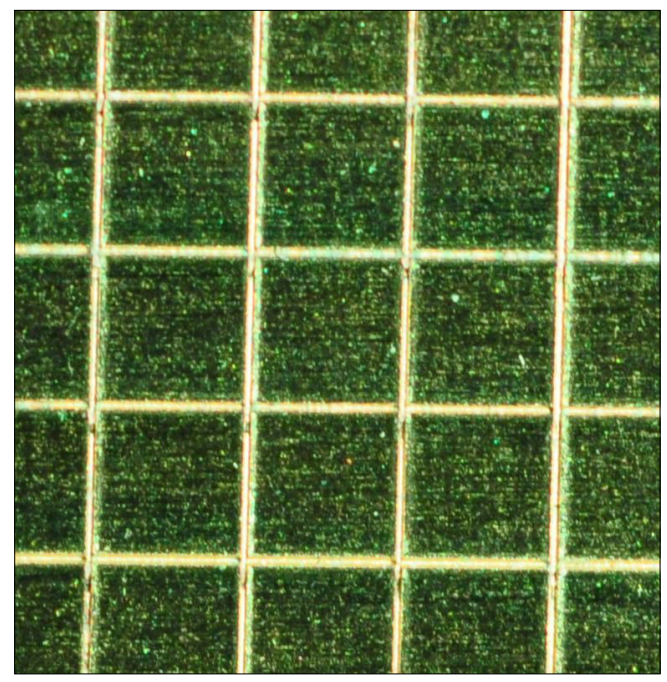

Fot. 4. Spodnia warstwa: 15\% Sandarak w alkoholu butylowym + barwnik Savinyl Gelb RLSN Clariant. Wierzchnia warstwa: 20\% Szelak bielony w 1-metoksy-2-propanolu + barwnik Blau 807 BASF 


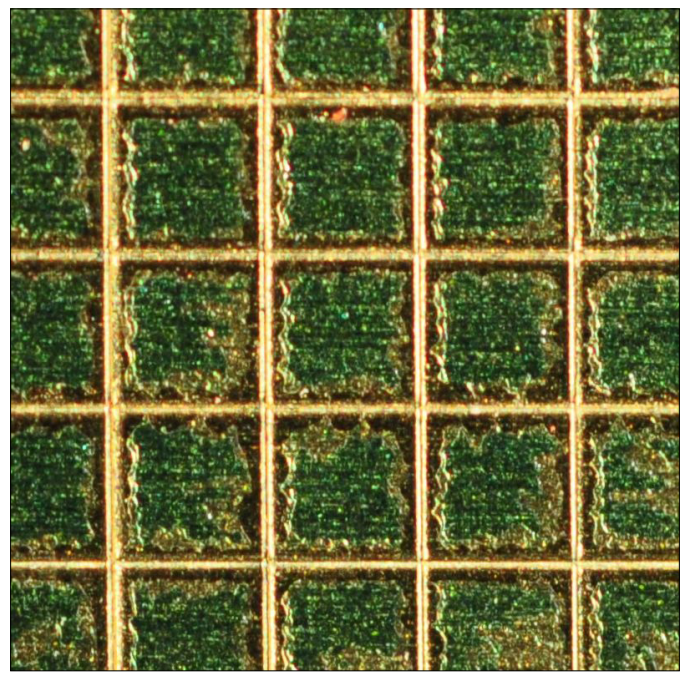

Fot. 5. Spodnia warstwa: Acrylic Varnish Glossy 114 Talens + farba olejna Indian Yellow 244 Van Gogh Talens. Wierzchnia warstwa: 20\% Paraloid B-72 w 1-metoksy-2-propanolu + barwnik Blau 807 BASF

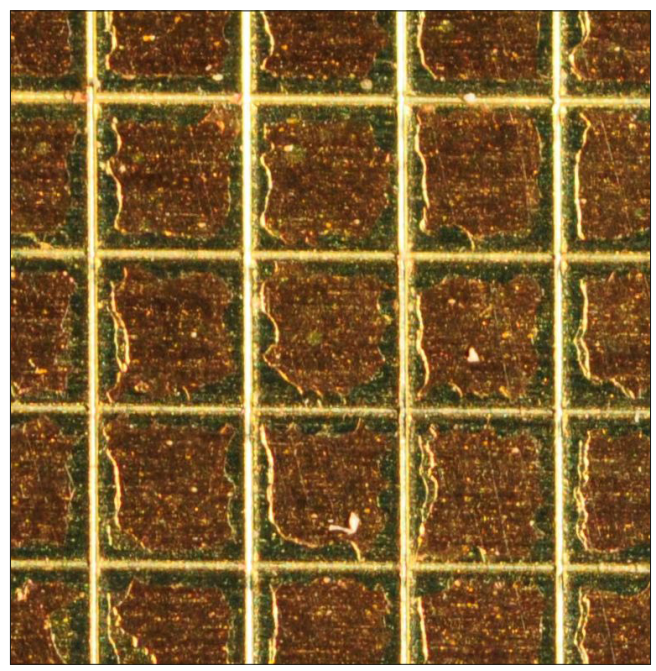

Fot. 6. Spodnia warstwa: Acrylic Varnish Glossy 114 Talens + farba olejna Indian Yellow 244 Van Gogh Talens. Wierzchnia warstwa: 11\% Paraloid B-48N w [acetonie + DPM (1:1)] + barwnik Savinyl Rot RLSN Clariant 


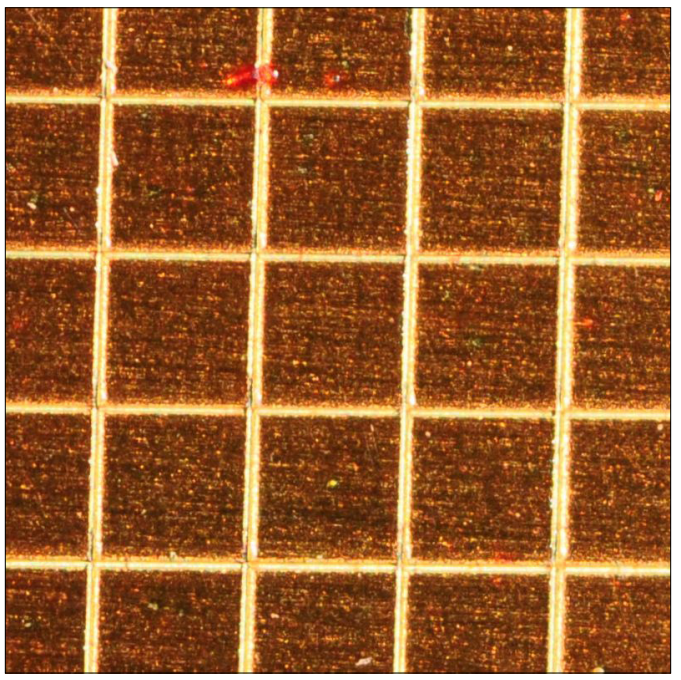

Fot. 7. Spodnia warstwa: Bernsteinlack echt Kremer + farba olejna Indian Yellow 244 Van Gogh Talens. Wierzchnia warstwa: Decorfin Glass Red 300 Talens + white spirit D 40 (2:1)

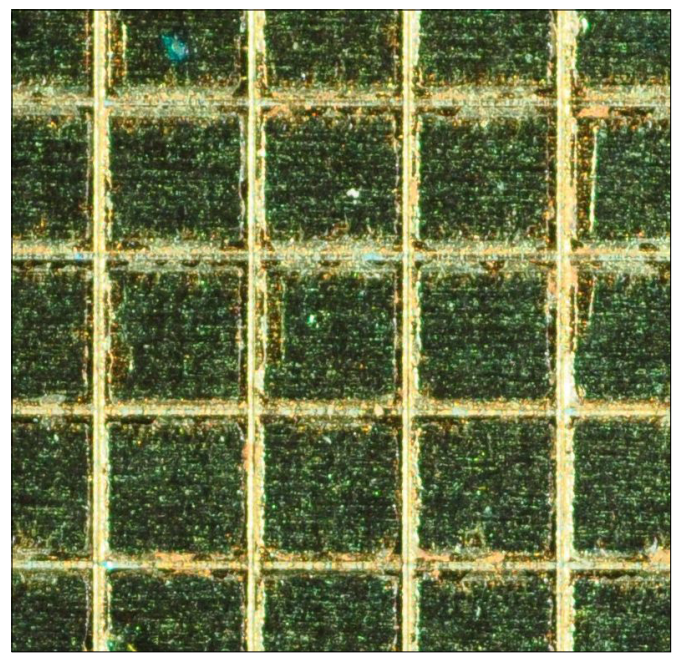

Fot. 8. Spodnia warstwa: Incral $44+$ barwnik Savinyl Gelb RLSN Clariant. Wierzchnia warstwa: Damara Varnish Glossy 081 Talens + farba olejna Phthalo Blue 570 Rembrandt Talens 